Prepared in cooperation with the Bureau of Reclamation

\title{
Dispersal of Larval Suckers at the Williamson River Delta, Upper Klamath Lake, Oregon, 2006-09
}

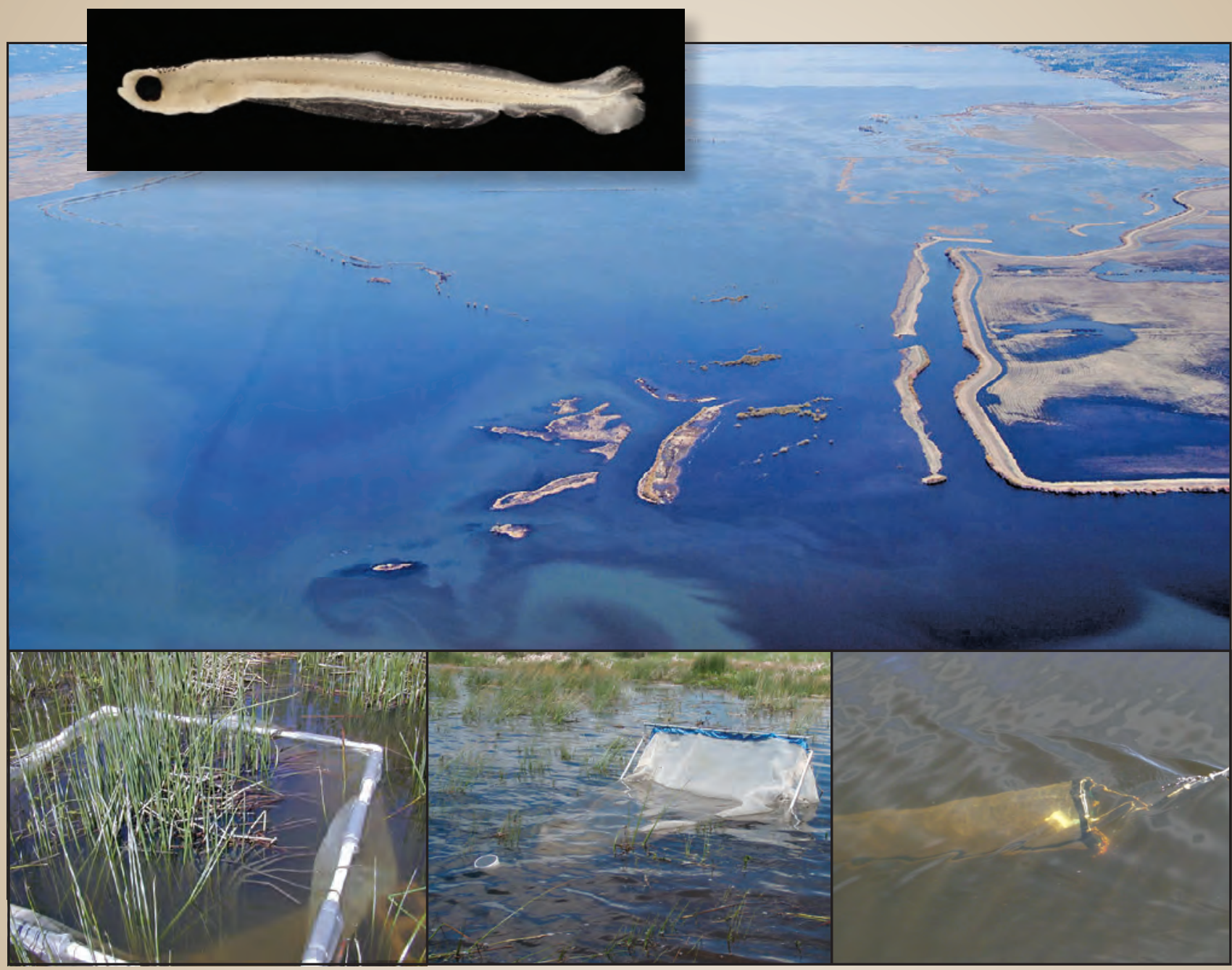

Scientific Investigations Report 2012-5016 


\section{Cover:}

Inset: Larval sucker from Upper Klamath Lake, Oregon. (Photograph taken by Allison Estergard, Student, Oregon State University, Corvallis, Oregon, 2011.)

Top: Photograph taken from the air of the flooded Williamson River Delta, Upper Klamath Lake, Oregon. (Photograph taken by Charles Erdman, Fisheries Technician, Williamson River Delta Preserve, Klamath Falls, Oregon, 2008.)

Bottom left: Photograph of a pop net used by The Nature Conservancy to collect larval suckers in Upper Klamath Lake and the Williamson River Delta, Oregon.

(Photograph taken by Heather Hendrixson, Director, Williamson River Delta Preserve, Klamath Falls, Oregon, 2006.)

Bottom middle: Photograph of a larval trawl used by Oregon State University to collect larval suckers in Upper Klamath Lake and the Williamson River Delta, Oregon. (Photograph taken by David Simon, Senior Faculty Research Assistant, Oregon State University, Corvallis, Oregon, 2010.)

Bottom right: Photograph of a plankton net used by the U.S. Geological Survey to collect larval suckers in Upper Klamath Lake and the Williamson River Delta, Oregon. (Photographer unknown, Klamath Falls, Oregon, 2009.) 


\section{Dispersal of Larval Suckers at the Williamson River Delta, Upper Klamath Lake, Oregon, 2006-09}

By Tamara M. Wood, U.S. Geological Survey, Heather A. Hendrixson, The Nature Conservancy, Douglas F. Markle, Oregon State University, Charles S. Erdman, The Nature Conservancy, Summer M. Burdick, U.S. Geological Survey, Craig M. Ellsworth, U.S. Geological Survey, and Norman L. Buccola, U.S. Geological Survey

Prepared in cooperation with the Bureau of Reclamation

Scientific Investigations Report 2012-5016 


\title{
U.S. Department of the Interior \\ KEN SALAZAR, Secretary \\ U.S. Geological Survey \\ Marcia K. McNutt, Director
}

\author{
U.S. Geological Survey, Reston, Virginia: 2012
}

For more information on the USGS - the Federal source for science about the Earth, its natural and living resources, natural hazards, and the environment, visit http://www.usgs.gov or call 1-888-ASK-USGS.

For an overview of USGS information products, including maps, imagery, and publications, visit http://www.usgs.gov/pubprod

To order this and other USGS information products, visit http://store.usgs.gov

Any use of trade, product, or firm names is for descriptive purposes only and does not imply endorsement by the U.S. Government.

Although this report is in the public domain, permission must be secured from the individual copyright owners to reproduce any copyrighted materials contained within this report.

Suggested citation:

Wood, T.M., Hendrixson, H.A., Markle, D.F., Erdman, C.S., Burdick, S.M., Ellsworth, C.M., and Buccola, N.L., 2012, Dispersal of larval suckers at the Williamson River Delta, Upper Klamath Lake, Oregon, 2006-09: U.S. Geological Survey Scientific Investigations Report 2012-5016, 28 p. 


\section{Contents}

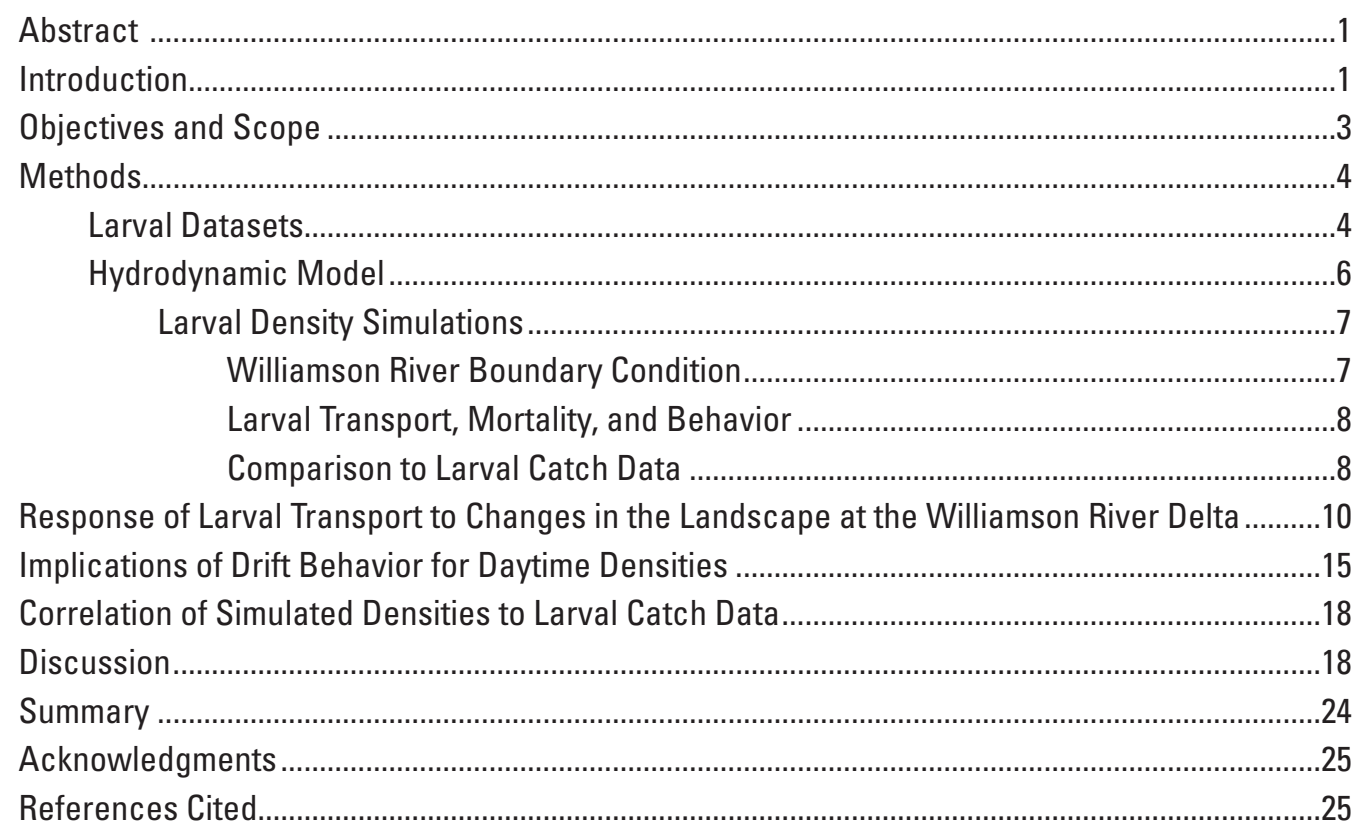




\section{Figures}

Figure 1. Map showing Upper Klamath and Agency Lakes, Oregon, after restoration of the Williamson River Delta was completed in November 2008

Figure 2. Maps showing three shoreline configurations of the Williamson River Delta between 2007 and 2009, Upper Klamath and Agency Lakes, Oregon

Figure 3. Graphs showing measured larval drift and time series of the model boundary condition for fish density at the Modoc Point Road bridge, Upper Klamath Lake, Oregon, 2006-09

Figure 4. Wind rose diagrams showing wind direction and speed data collected at the Williamson River Delta, Upper Klamath Lake, Oregon

Figure 5. Graphs showing simulated density of larval suckers at larval catch sites (except WR) in the Williamson River Delta, Oregon, 2006-09

Figure 6. Graphs showing discharge of Williamson River and elevation of Upper Klamath Lake, Oregon, between May and July 2006-09

Figure 7. Graphs showing simulated density of larval suckers at larval catch sites in Upper Klamath Lake, Oregon, 2006-09

Figure 8. Graphs showing simulated density of larval suckers at larval catch sites in Agency Lake, Oregon, 2008-09

Figure 9. Graphs showing simulated density of larval suckers at site A, Williamson River Delta, Oregon.

Figure 10. Graphs showing simulated density of larval suckers at site B, Williamson River Delta, Oregon.

Figure 11. Graphs showing simulated density of larval suckers at site D, Williamson River Delta, Oregon.

Figure 12. Graphs showing catch density of larval suckers at sites in the Williamson River Delta and at the mouth of the Williamson River, Oregon, 2006-09

Figure 13. Graphs showing catch density of larval suckers at sites in Upper Klamath Lake, Oregon, 2006-09

Figure 14 Graphs showing catch density of larval suckers at sites in Agency Lake, Oregon, 2006-09

\section{Tables}

Table 1. Summary of larval catches in three gear types, Upper Klamath Lake, Oregon, 2006-09

Table 2. Spearman correlation coefficients between the density of larval suckers captured at larval catch sites and the simulated density at each site, Upper Klamath and Agency Lakes, Oregon, 2006-09

Table 3. Characteristics of the net catches in the drift at Modoc Point Road bridge and for three different gear types, Upper Klamath Lake, Oregon, 2006-09 


\section{Conversion Factors and Datums}

Conversion Factors

Inch/Pound to SI

\begin{tabular}{|c|c|c|}
\hline Multiply & By & To obtain \\
\hline \multicolumn{3}{|c|}{ Length } \\
\hline inch (in.) & 2.54 & centimeter (cm) \\
\hline inch (in.) & 25.4 & millimeter (mm) \\
\hline mile (mi) & 1.609 & kilometer (km) \\
\hline \multicolumn{3}{|c|}{ Flow rate } \\
\hline cubic foot per second $\left(\mathrm{ft}^{3} / \mathrm{s}\right)$ & 0.02832 & cubic meter per second $\left(\mathrm{m}^{3} / \mathrm{s}\right)$ \\
\hline
\end{tabular}

SI to Inch/Pound

\begin{tabular}{lll}
\hline \multicolumn{1}{c}{ Multiply } & By & \multicolumn{1}{c}{ To obtain } \\
\hline millimeter $(\mathrm{mm})$ & Length & \\
meter $(\mathrm{m})$ & 0.03937 & inch (in.) \\
kilometer $(\mathrm{km})$ & 3.281 & foot $(\mathrm{ft})$ \\
& 0.6214 & mile (mi) \\
\hline square meter $\left(\mathrm{m}^{2}\right)$ & Area & \\
hectare $($ ha) & 10.76 & square foot $\left(\mathrm{ft}^{2}\right)$ \\
\hline & 0.003861 & square mile $\left(\mathrm{mi}^{2}\right)$ \\
\hline cubic meter $\left(\mathrm{m}^{3}\right)$ & Volume & \\
cubic meter $\left(\mathrm{m}^{3}\right)$ & 35.31 & cubic foot $\left(\mathrm{ft}^{3}\right)$ \\
\hline & 0.0008107 & acre-foot $(\mathrm{acre}-\mathrm{ft})$ \\
\hline cubic meter per second $\left(\mathrm{m}^{3} / \mathrm{s}\right)$ & Flow rate & \\
\hline
\end{tabular}

Datums

Vertical coordinate information is referenced to the Bureau of Reclamation datum, which is 1.78 feet above National Geodetic Vertical Datum of 1929 (NGVD 29).

Horizontal coordinate information is referenced to the North American Datum of 1927 (NAD 27).

Elevation, as used in this report, refers to distance above the vertical datum. 
This page intentionally left blank. 


\title{
Dispersal of Larval Suckers at the Williamson River Delta, Upper Klamath Lake, Oregon, 2006-09
}

\author{
Tamara M. Wood, U.S. Geological Survey, Heather A. Hendrixson, The Nature Conservancy, \\ Douglas F. Markle, Oregon State University, Charles S. Erdman, The Nature Conservancy, \\ Summer M. Burdick, U.S. Geological Survey, Craig M. Ellsworth, U.S. Geological Survey, and \\ Norman L. Buccola, U.S. Geological Survey
}

\section{Abstract}

An advection/diffusion modeling approach was used to simulate the transport of larval suckers from spawning areas in the Williamson River, through the newly restored Williamson River Delta, to Upper Klamath Lake. The density simulations spanned the years of phased restoration, from 2006/2007 prior to any levee breaching, to 2008 when the northern part of the delta was reconnected to the lake, and 2009 when levees on both sides of the delta had been breached. Model simulation results from all four years were compared to field data using rank correlation. Spearman $\rho$ correlation coefficients were usually significant and in the range 0.30 to 0.60 , providing moderately strong validation of the model. The correlation coefficients varied with fish size class in a way that suggested that the model best described the distribution of smaller fish near the Williamson River channel, and larger fish away from the channel. When Lost River and shortnose/Klamath largescale suckers were simulated independently, the correlation results suggested that the model better described the transport and dispersal of the latter species. The incorporation of night-time-only drift behavior in the Williamson River channel neither improved nor degraded correlations with field data. The model showed that advection by currents is an important factor in larval dispersal.

\section{Introduction}

Deltaic marshes at the mouth of the Williamson River were once among the most important habitats for larvae of the endangered Lost River sucker Deltistes luxatus and shortnose sucker Chasmistes brevirostris, due to their location downstream of known productive spawning grounds. In 1996, The Nature Conservancy purchased the property surrounding the mouth of the Williamson River and began a large-scale restoration project that would ultimately reconnect the Williamson River with 2,500 ha of land that had, prior to the 1940s, composed the wetlands of the Williamson River Delta (hereafter referred to as the Delta). In October, 2007, the levees around the northern half of the Delta, referred to as Tulana (fig. 1), were breached mechanically and with a series of explosions to reconnect it to Upper Klamath Lake, flooding approximately 1,500 ha of former agricultural land. Then in November, 2008, roughly 1,000 ha of land in the southern half of the Delta, known as Goose Bay (fig. 1), was flooded through mechanical removal of several large sections of levee. A primary goal of this restoration project was to restore the function of these wetlands as nursery habitat for the endangered Lost River and shortnose suckers, endemic to the Upper Klamath Basin.

Lost River and shortnose suckers are long-lived (as much as several decades), iteroparous lake dwellers that typically travel into the tributaries to spawn in the early spring (Scoppettone and Vinyard, 1991; Terwilliger and others, 2010). Upper Klamath Lake is the current population stronghold for both species. Large numbers spawn in the Williamson River between river kilometers 10 and 17.5 (the delta apex is at about river kilometer 5.6), in the Sprague River upstream of the confluence with the Williamson River, and as far upstream as river kilometer 120 (Ellsworth and others, 2011). In addition, a small cohort of Lost River suckers spawn at lakeshore spring areas along the eastern edge of the lake (Janney and others, 2008). After the larvae leave the gravel at the spawning grounds, they immediately begin drifting downstream at night with the river flow (Cooperman and Markle, 2003; Ellsworth and others, 2009). Before restoration, the travel time between spawning grounds and Upper Klamath Lake was as short as 1 day, resulting in many larvae entering the lake prior to caudal fin formation and yolk sac absorption (Cooperman and Markle, 2003). Age-0 sucker habitat use has been described as consisting of nearshore, vegetated areas as well as deeper, open water areas of Upper Klamath Lake and can vary depending on water quality conditions (Reiser and others, 2001; Cooperman and Markle, 2004; Crandall and others, 2008; Burdick and Brown, 2010; Burdick and Vanderkooi, 2010). 


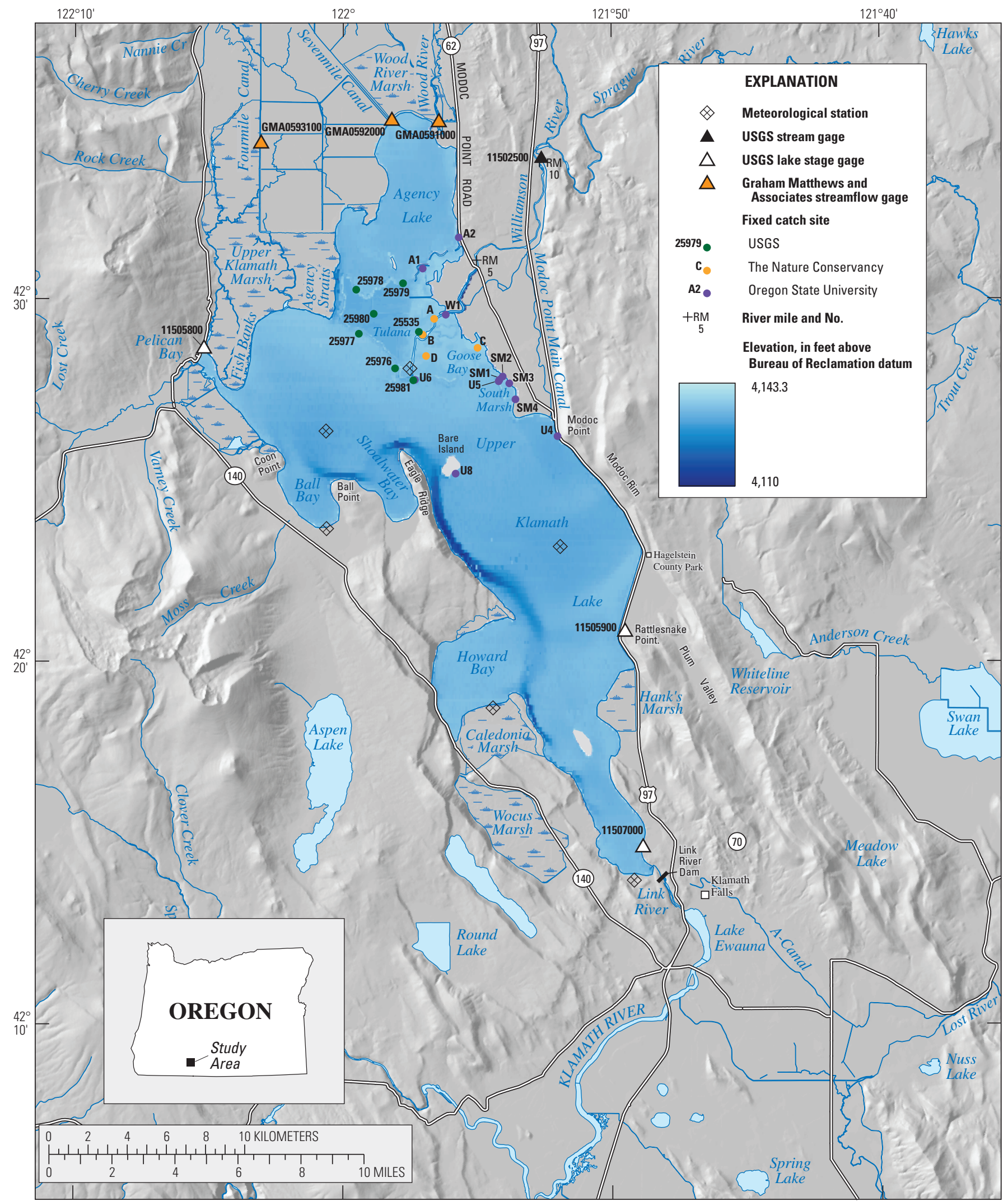

Base modified from USGS and other digital sources, various scales.

Coordinate system is UTM, Zone 10N; North American Datum of 1927

Figure 1. Upper Klamath and Agency Lakes, Oregon, after restoration of the Williamson River Delta was completed in November 2008. Fixed larval catch sites occupied by the U.S. Geological Survey (USGS), The Nature Conservancy, and Oregon State University are shown. 
The restoration of the Delta created myriad complex pathways connecting the lower $3 \mathrm{mi}$ of the Williamson River channel to Upper Klamath and Agency Lakes, which should increase the travel time to the lakes for many of the larvae (Markle and others, 2009). The increase in emergent vegetation associated with wetland restoration at the Delta is expected to provide sanctuary from wind turbulence (Cooperman and others, 2010), ample feeding and growing opportunities (Crandall and others, 2008), and predator protection (Markle and Clausen, 2006; Markle and Dunsmoor, 2007). All of these, in combination with the increase in time between swim-up and entry to the lakes, could potentially contribute to a strong year class formation and aid in recovering these species.

It is of interest to stakeholders to know if the restoration has been successful and to what extent larvae are using the Delta, as well as the differences in the size and age of sucker larvae that are found in the lakes after having spent time in the newly restored wetlands. Collecting fish samples in an area as large as the Delta and surrounding lake habitats is resource intensive, and cannot be done with the spatial and temporal resolution required to resolve the true variability in the system. With properly defined boundary conditions, numerical models that simulate the transport of larvae are a useful means of augmenting net catches by providing information at temporal and spatial scales that otherwise is unattainable. A model can both help biologists visualize what is happening over the large area of the Delta, and, where model simulations differ from direct observations, can provide guidance as to where assumptions about larvae behavior that are embodied in the model have broken down. Furthermore, once confidence in a model is established, it can be used to predict how larval transport might differ under different scenarios for the active management of the system, primarily in terms of the lake elevation, for a given Williamson River flow and meteorological conditions.

The application of models to the dispersal of larvae in marine environments has received much attention in the literature in the past several decades. These studies are designed with one of three problems in mind:

(1) connectivity - the movement of larvae between geographically separated populations (Hare and others, 2002; Nahas and others, 2003; Paris and others, 2009; Watson and others, 2010), (2) adaptive sampling - the real-time modification of sampling strategies in order to most effectively sample a population (Pepin and others, 2009), and (3) recruitment prediction - the number of fish reaching a defined size, age, development stage, or suitable nursery habitat (Reyns and others, 2006; Hinckley and others, 2009; Mariani and others, 2010). Examples of models applied to the problems of freshwater dispersal are fewer (Beletsky and others, 2007). Marine larval dispersal typically takes place over larger spatial scales and longer time scales than are pertinent to the problem of the dispersal of sucker larvae through the Delta. Marine applications typically include vertical as well as horizontal variability. In this study, done in cooperation with the Bureau of Reclamation, the relevant concepts that have been developed for marine larval dispersal were adapted to a large, shallow lake with a complex spatial geometry in which the currents are primarily wind driven. In analogy to the recruitment prediction problem in the marine environment, the goal is to understand how the physical reconfiguration of the landscape at the Delta and environmental conditions (Williamson River flow, lake stage, and meteorology) determine the distribution of a larval cohort after it leaves the spawning grounds (that is, the number of fish that will occupy the habitat on both sides of the Delta before entering the open waters of the lake).

\section{Objectives and Scope}

This report presents the results of a modeling study of the transport of larval suckers from spawning grounds in the Williamson River, through the Williamson River Delta, and into Upper Klamath and Agency Lakes. Water currents simulated with a calibrated hydrodynamic model for the Upper Klamath and Agency Lake system (Wood and others, 2008) were used in this study to transport the larvae through the combined Upper Klamath Lake/Agency Lake/ Williamson River Delta system. This modeling approach was used to address three objectives. First, the effect of opening up both sides of the Delta on larval transport and on larval catches at the mouth of the Williamson River and along the shorelines in Upper Klamath and Agency Lakes was described. Second, the implications of nighttime-only drift behavior for sampling strategies at larval catch sites within the Delta were examined. Third, the accuracy of the model assumptions was assessed by comparing model simulations to measurements of larval density. Qualitative and quantitative (using rank order correlation analysis) comparisons were made between the simulated results and larval catches. Several examples of qualitative comparisons between simulated fish densities and model simulations were found in the literature (Ellien and others, 2004; Arnold and others, 2005; Petrone and others, 2005, Mariani and others, 2010); however, attempts to quantitatively assess the performance of a model in simulating fish densities by comparing to measurements from net catches as done in this study appear to be rare.

In pursuing these objectives, we used a density (advection-diffusion equation) approach. The density approach is limited to describing the advective transport of larvae by currents, in combination with passive diffusion, and therefore cannot be used to simulate the active dispersal resulting from horizontal swimming. Nighttime-only drift was incorporated, even though it is non-passive behavior, by "freezing" the density in the river channel during the day. The advantage of this approach is that it yields concentration information at all locations within the numerical grid at fine temporal resolution, and therefore allows the comparison of simulated results directly to larval catch densities. 


\section{Methods}

\section{Larval Datasets}

The larval catch data used for this report were collected by three agencies: Oregon State University (OSU), The Nature Conservancy (TNC), and the USGS. Larvae were collected during 4 years between 2006 and 2009 at fixed sites by TNC and OSU and at random sites by TNC. The USGS collected larvae in 2008 and 2009 at fixed and random sites. Twenty-two fixed sites (fig. 1) were visited multiple times during a season, and were consistent across years, whereas random sites (fig. 2) were visited once and not intentionally repeated within a season. Qualitative differences in the sites visited by the different agencies are apparent. The OSU sites used in this study, with the exception of site W1, were outside of the Delta and close to the shoreline in either Upper Klamath Lake or Agency Lake. The TNC sites were in shallow water (less than $1.0 \mathrm{~m}$ deep) either in the Delta or along the levees. The USGS sites were in deeper water than the OSU and TNC sites and consequently farthest from shorelines or levees (primarily within Tulana) and also in Upper Klamath and Agency Lakes across from the levee openings.

Oregon State University data were collected during daylight using a larval trawl (table 1) having a $2.5 \mathrm{~m}$ long, $1 \mathrm{~mm}$ bar mesh Nitex ${ }^{\circledR}$ net with a $0.8 \times 1.5 \mathrm{~m}$ opening mounted on an aluminum frame with runners (LaBolle and others, 1985). The trawl was set 3-12 m offshore in water as much as $1 \mathrm{~m}$ deep (range $0.2-1.0 \mathrm{~m}$ ), allowed to soak for 10 minutes, then pulled to shore with ropes. Sampling from 2006 to 2009 took place the first full week of April through late July, with samples collected at the fixed sites every third week for a total of six sampling surveys. In Upper Klamath Lake, two samples were collected from each of ten fixed sites from 2006 to 2007 (fig. 1). The mouth of the Williamson River changed because of restoration in late 2007. Both the former river mouth site (OSU-W1) and the new river mouth site (OSU-U6) were sampled in 2008 and 2009. In Agency Lake, two samples were collected from each of two fixed sites. Two samples collected at a single site were considered replicates for the purposes of this study.

The Nature Conservatory data were collected during daylight in pop nets set in water as much as $1 \mathrm{~m}$ deep (range 0.1-1.0 m). The nets consisted of two 1 in diameter PVC frames (each approximately $2.56 \mathrm{~m}^{2}$ ), one weighted with rebar to serve as the lead line and the other wrapped in foam core to act as a float. One-meter wide, fine mesh mosquito netting connected the two frames to form a cube. The nets were open at the bottom and top, allowing them to be set in vegetation. To set the nets, both frames were submerged and secured underwater with two cinderblocks. A long line attached to each cinderblock enabled them to be pulled away from the net without disturbing the sampling area and allowed the foam-wrapped upper frame to "pop" up, enclosing the section of water. Each net was set for a minimum of 30 minutes prior to sampling to ensure each site had recovered from disturbances resulting from setting the net. Two to four samples were collected at each site, usually within 1 hour of each other. These samples were considered to be replicates for the purposes of this study, although generally one net was set in emergent or submerged vegetation and one was set nearby on substrate with no vegetation, and the depth sometimes varied between the replicate nets.

In 2006 and 2007, pop nets were set in South Marsh and two lakeshore fringe wetlands in Upper Klamath Lake along the Goose Bay shoreline (fig. 2). After restoration in November 2007, the Tulana area of the delta was added to the aforementioned sampling areas for the 2008 sampling period; Goose Bay, after being flooded in October 2008, was added in 2009 (fig. 2). Each sampling area was visited every other week in 2006 and 2008 and weekly in 2007 and 2009. A maximum of eight nets were set at random points within each sampling area each week; however, beginning in 2008 two fixed sites were visited weekly in Tulana and beginning in 2009, two fixed sites were visited weekly in Goose Bay (fig. 1).

The USGS used plankton nets during daylight to collect larvae from the top of the water column. These nets had $0.3 \mathrm{~m}$ diameter mouth openings, a $2.5 \mathrm{~m}$ long tail, $800 \mu \mathrm{m}$ mesh Nitex netting, and a removable cod end. A General Oceanics, model 2030R, mechanical flowmeter was mounted in the mouth of each net so that the volume sampled could be calculated. The net was towed parallel to a boat at approximately $1 \mathrm{~m} / \mathrm{s}$ for 3-5 minutes or until algae began to clog the mesh. After retrieval, all material was meticulously removed from nets and samples were immediately preserved in 70-95 percent ethanol. One, two, or three replicate tows were performed at each site.

The USGS sites consisted of both random and fixed sites. The random sites were selected using a stratified design from deep (greater than $1.5 \mathrm{~m}$ ) areas in Agency Lake, Tulana, and Upper Klamath Lake, and two shallow (0.5-1.1 m) areas in Tulana (Burdick and Brown, 2010, fig. 2). In 2008, USGS located fixed sites on the lake side of the four breaches that were made in the levees surrounding Tulana (sites 25976, 25977, 25978, and 25979); in open water inside Tulana (site 25980); in about $1 \mathrm{~m}$ of water on the east side of Tulana (site 25535); and offshore of the mouth of the Williamson River (site 25981) (fig. 1). In 2009, additional fixed sites were added in the Goose Bay oxbow, nearshore in the western part of Goose Bay, and offshore in the eastern part of Goose Bay (not shown in fig. 1). 
A.

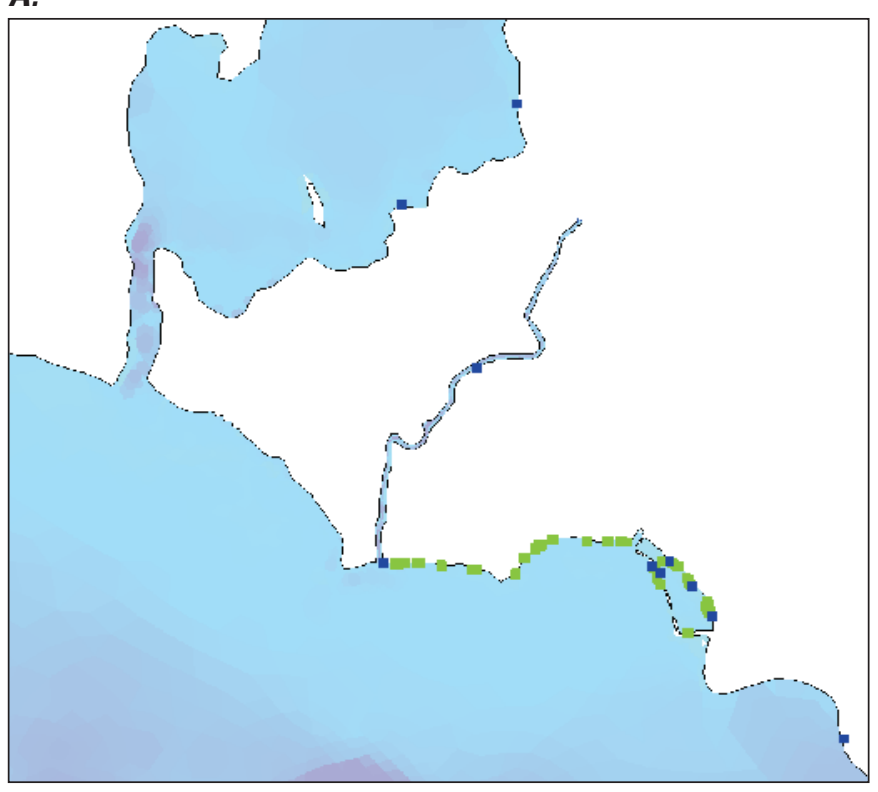

B.

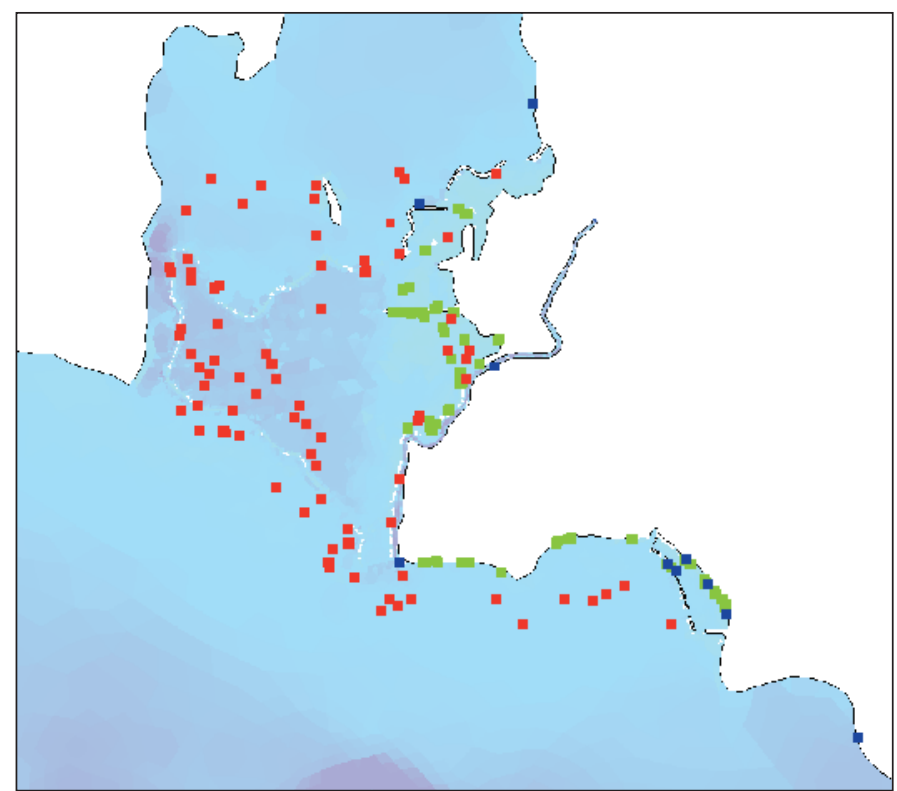

c.

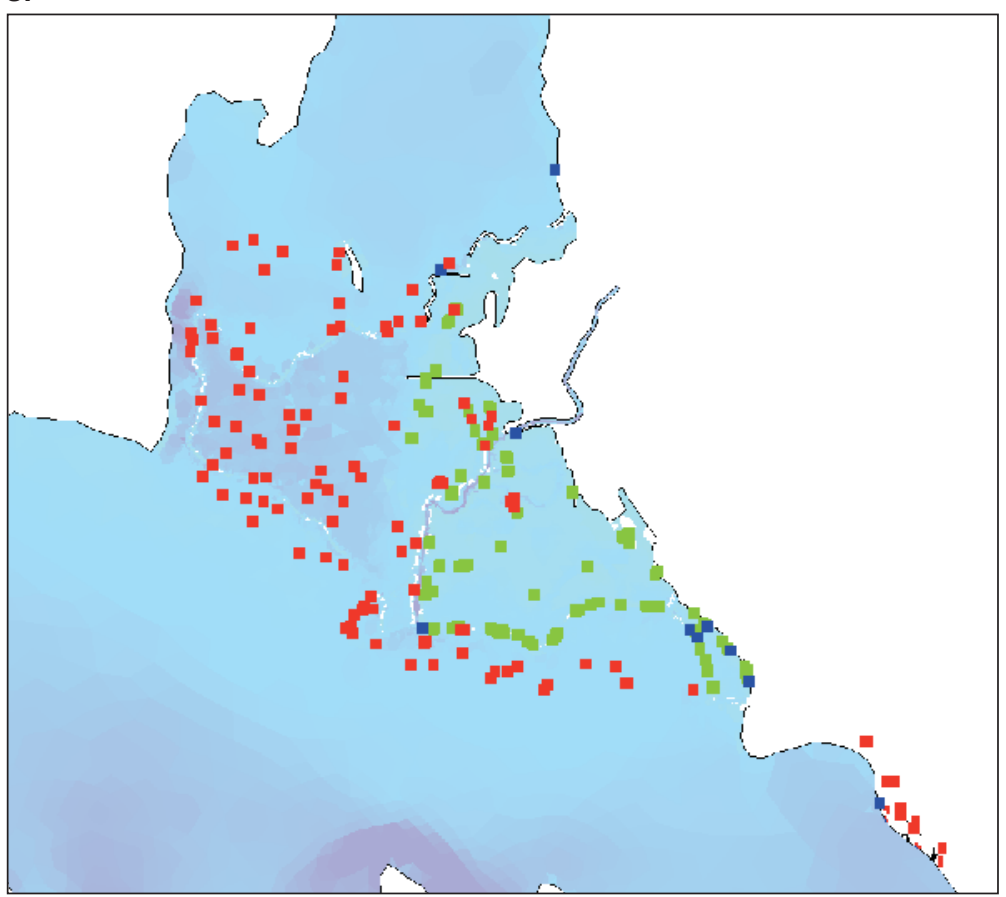

EXPLANATION

Larval sampling sites, fixed and random

- Oregon State University

- The Nature Conservancy

- U.S. Geological Survey

Depth, in meters

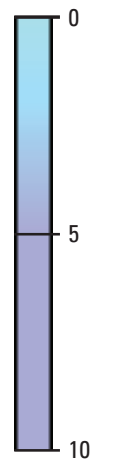

Figure 2. Three shoreline configurations of the Williamson River Delta between 2007 and 2009, Upper Klamath and Agency Lakes, Oregon. The shoreline configuration in 2006 (not shown) was the same as in 2007. 
Table 1. Summary of larval catches in three gear types, Upper Klamath Lake, Oregon, 2006-09.

[Pop nets were set by The Nature Conservancy; larval trawls were set by Oregon State University; plankton nets were set by the U.S. Geological Survey. Small: fish sized 10-13 mm; M id: fish sized >13-16 mm; Large: fish sized >16-19 mm. Abbreviations: >, greater than; /, no larval catch data; mm, millimeter]

\begin{tabular}{|c|c|c|c|c|c|c|c|c|c|c|c|c|c|}
\hline \multirow{3}{*}{ Year } & \multirow{3}{*}{$\begin{array}{l}\text { Restoration } \\
\text { status }\end{array}$} & \multicolumn{4}{|c|}{ Larval trawls } & \multicolumn{4}{|c|}{ Pop nets } & \multicolumn{4}{|c|}{ Plankton nets } \\
\hline & & \multirow{2}{*}{$\begin{array}{c}\text { Total } \\
\text { number } \\
\text { of nets } \\
\text { set }\end{array}$} & \multicolumn{3}{|c|}{$\begin{array}{l}\text { Total number of fish } \\
\text { caught by size }\end{array}$} & \multirow{2}{*}{$\begin{array}{c}\text { Total } \\
\text { number } \\
\text { of nets } \\
\text { set }\end{array}$} & \multicolumn{3}{|c|}{$\begin{array}{l}\text { Total number of fish } \\
\text { caught by size }\end{array}$} & \multirow{2}{*}{$\begin{array}{c}\text { Total } \\
\text { number } \\
\text { of nets } \\
\text { set }\end{array}$} & \multicolumn{3}{|c|}{$\begin{array}{l}\text { Total number of fish } \\
\text { caught by size }\end{array}$} \\
\hline & & & Small & Mid & Large & & Small & Mid & Large & & Small & Mid & Large \\
\hline 2006 & Levees intact & 106 & 518 & 518 & 165 & 138 & 548 & 440 & 128 & I & / & I & I \\
\hline 2007 & Levees intact & 100 & 26 & 264 & 86 & 178 & 449 & 785 & 257 & 1 & 1 & / & 1 \\
\hline 2008 & $\begin{array}{l}\text { Levees breached around } \\
\text { Tulana }\end{array}$ & 114 & 363 & 523 & 187 & 207 & 419 & 777 & 205 & 228 & 572 & 66 & 4 \\
\hline 2009 & $\begin{array}{l}\text { Levees breached around } \\
\text { Goose Bay }\end{array}$ & 117 & 154 & 105 & 50 & 244 & 408 & 448 & 79 & 331 & 195 & 42 & 0 \\
\hline
\end{tabular}

Samples collected by each agency were either fixed in 10 percent formalin, and later switched to 50 percent isopropanol for long-term storage, or preserved in 70-95 percent ethanol. Smaller catostomid larvae, less than $14 \mathrm{~mm}$ in the OSU catches or less than $15 \mathrm{~mm}$ in the USGS and TNC catches, were identified as either Lost River suckers or a grouping of shortnose and Klamath largescale suckers based on pigmentation patterns. Identical protocols were used by all agencies to identify species (Simon and others, unpub. data) and results were cross checked to minimize bias. There is no method for distinguishing between larval shortnose and Klamath largescale suckers. Some suckers had indeterminate patterns and were classified as unidentified suckers. The method of classification of larger catostomid larvae was different at each agency. At TNC, larvae larger than $15 \mathrm{~mm}$ were classified as unidentified suckers. At USGS, post-Weberian vertebrae of larvae over $15 \mathrm{~mm}$ were counted if they were visible and if the species was in doubt. Those with greater than 44 vertebrae were classified as Lost River suckers, those with less than 44 vertebrae were classified as shortnose/ Klamath largescale suckers, and those with 44 vertebrae were classified as unidentified suckers (Markle and others, 2005). At OSU, fish larger than $14 \mathrm{~mm}$ were cleared and stained (Potthoff, 1984). Post-Weberian vertebrae were counted on these fish, and species assigned based on post-Weberian vertebral counts as previously indicated.

Because some samples were fixed in formalin while others were preserved in ethanol, differential larval shrinkage may have introduced some degree of bias in the results. Nominal concentrations were 10 percent formalin and 70-95 percent ethanol, but the inability to make precise mixtures in the field could also contribute to differential shrinkage. Most shrinkage occurs within 1 day and in a study of larval inland silversides, mean shrinkage after 21 days was 3.9-4.1 percent for 80-100 percent ethanol and 2.2-3.2 percent for 5-10 percent formalin (Cunningham and others, 2000). Because the larvae used for otolith ageing followed the methods of Terwilliger and others (2003) and were preserved in ethanol, all measurements include shrinkage from live lengths and age estimates are based on shrinkage of perhaps 4 percent. The 1-2 percent difference in shrinkage between formalin and ethanol is considered trivial for our analyses and no corrections were made.

\section{Hydrodynamic Model}

The UnTRIM hydrodynamic model solves the governing equations for flow and transport on an orthogonal unstructured grid using the efficient and stable algorithms of Casulli and Zanolli (2002). The details of the three-dimensional Upper Klamath Lake model and its calibration and validation for 2005 and 2006 (Wood and others, 2008) are provided elsewhere and not repeated here. A one-layer version of the UnTRIM hydrodynamic model of the lake described in Wood and others (2008) was used in order to speed computation time. The use of a one-layer model removes the effects of water density on the flow, which is not important in the present analysis. In this case, because transport through the Delta is the primary interest, and the flow is expected to be well-described by two dimensions, the benefit of running more simulations in the available time outweighed the loss of accuracy that occurred by using a one-layer model.

The unstructured orthogonal grid used in the UnTRIM model is particularly well-suited to describing the small scale features and complicated boundaries associated with the Williamson River channel and the levees remaining around the channel and the Delta. The elevations within the Delta were obtained from a composite of data interpolated to a grid with $100 \mathrm{ft}$ horizontal spacing (L. Friend, ZCS Engineering, Inc., written commun., 2009). The grid was built from pre-project survey data, in combination with the engineered 
design modifications for the project, and then modified with additional surveys to collect data where the design elevations differed from the "as built" elevations. These data were used to generate the bathymetry data in the new Williamson River and Delta parts of the grid, which were then merged into the existing grid for the rest of the lake. Because this study spans the years 2006 through 2009, three versions of the numerical grid were used. A "pre-project" grid was used for 2006 and 2007 simulations. Tulana was flooded in autumn 2007, and therefore a grid that included only that side of the Delta was used for the 2008 simulations. Goose Bay was flooded in autumn 2008, and therefore a grid incorporating both the Tulana and Goose Bay sides of the Delta was used for 2009 simulations (fig. 2). All three grids incorporated the Williamson River channel upstream to the Modoc Point Road bridge (river kilometer 7.4). A Manning formulation was used for the bottom friction in these new areas of the grid. A Manning's $n$ of 0.026 was used within the channel, to be consistent with a calibrated one-dimensional HEC-RAS model (Graham Matthews and Associates, 2001), and a Manning’s $n$ of 0.05 was used in the Tulana and Goose Bay parts of the Delta, also consistent with Graham Matthews and Associates (2001) and Daraio and others (2004).

The boundary conditions needed to run the model include wind forcing at the surface and inflows at the Williamson and Wood Rivers, as well as the outflow at the Link River Dam. The wind forcing was obtained from a spatial interpolation of 10-minute data collected at six meteorological sites (fig. 1). Because critical wind data from rafts located on the lake were not always available as early in the spring as required for simulations of larval drift from spawning sites in the Williamson River, some of the wind data from rafts was reconstructed using the artificial neural networks technique described in Buccola and Wood (2010). Missing wind data for May 10-16, 2006, and May 3-9, 2007 were reconstructed using this method.

The initial lake elevation and the elevations to which model elevations were compared came from three stage gages located around Upper Klamath Lake (fig. 1). Flow information is required at three boundaries: the Williamson River at Modoc Point Road, the Link River at the outlet of Upper Klamath Lake (the Link River Dam), and the Wood River, which empties into Agency Lake. Williamson River and Link River streamflows were obtained from USGS streamflow gaging stations (fig. 1). "Wood River," as used here, is the sum of inflows at the Wood River channel and two other canal flows, the Fourmile and Sevenmile canals, which are channelized diversions from the Wood River and empty into Agency Lake not far from the Wood River mouth. These flows were not recorded during the time period of this study, except Sevenmile flows in 2006. Flows from all three of these sources were recorded in 2004 and 2005 during May and June (Graham Matthews and Associates, 2009; fig. 1).
When the 2004 and 2005 data were combined, the average ratio of those combined flows to the Williamson River flow was approximately 0.6 . Therefore, the sum of these flows (Wood River, Fourmile Canal, and Sevenmile Canal) was set to a constant value of 0.6 times the average Williamson River flow for May 15 to June 30 in each year $(15.3,23.0,10.9$, and $28.7 \mathrm{~m}^{3} / \mathrm{s}$ in 2009, 2008, 2007, and 2006, respectively). The sensitivity of transport through the Delta to the value of the ratio of these flows to the Williamson River flow has been shown to be small (Wood, 2012).

\section{Larval Density Simulations}

The hydrodynamic model was used to simulate larval density during the springtime larval drift period of 2006 through 2009. The simulation period was 70 days in each year, starting about 4 days prior to the date when the first significant drift of larvae was observed at the Modoc Point Road bridge. The dates simulated were May 10-July 20, 2006; May 3July 13, 2007; May 15-July 25, 2008; and May 14-July 24, 2009.

\section{Williamson River Boundary Condition}

Larval-sucker density data collected in the thalweg at the Modoc Point Road (Tyler and others, 2004; Ellsworth and others, 2009) were used to construct the upstream boundary condition for a numerical tracer. Fish captured in the Williamson River drift at the Modoc Point Road were identified as either one of two taxa, Lost River sucker (LRS) or a group of suckers identified as either shortnose or Klamath largescale sucker (SNS/KLS), making it possible to use two tracers to simulate the Lost River and SNS/KLS sucker larvae separately. Fish with indeterminate characteristics were classified as unidentified suckers. The larvae tend to pass the Modoc Point Road bridge in two or more "pulses." The first pulse is dominated by LRS larvae, and subsequent pulses are dominated by SNS/KLS larvae. Because the larvae are known to drift at night, these drift data were usually collected between about 4-8 hours after sunset, and peaked between about 5-6 hours after sunset. To create a boundary condition, the larval drift data were first multiplied by a factor of 0.39 in order to compensate for higher drift concentrations near the surface and in the thalweg of the river than the average concentration over the cross section, which is the quantity needed for the boundary condition. This value was determined by analyzing cross-sectional larval density data collected at two transects of the Williamson River near Modoc Point Road (Tyler and others, 2004) during the peak nighttime drift hours between 10:00 in the evening and 3:00 in the morning, from May 8 to June 4, 2004 (Ellsworth and others, 2010). The value 0.39 represents a scaling of the cross-sectional area-weighted average of these larval densities by the larval density 
measurements taken in the thalweg of the river, where larval sampling occurred in successive years. To provide boundary information each night, gaps that occurred on evenings when crews were not collecting drift data were filled by replicating the data collected during the most recent evening when crews were collecting drift data. Therefore, gaps spanning more than 1 day were filled by repeating the most recent 24 -hour drift cycle that was sampled. The resulting concentration data, in units of fish per cubic meter, were applied to water entering the Williamson River boundary in the model grid. Larval drift was collected at intervals ranging from 0.5 to 2 hours; in order to match the 2-minute time step of the model, a measured value was used at every 2-minute time step until a new value was available. At sunrise each day, the boundary condition was set to zero; thus, no larvae were inserted into the model grid between sunrise and sunset. The time series of larval drift and the resulting model boundary condition for 2006-09 are shown in figure 3.

\section{Larval Transport, Mortality, and Behavior}

The model solves the advective-diffusive transport of larval fish using the differential equation:

$$
\begin{aligned}
\frac{\partial C}{\partial t}+\frac{\partial(u C)}{\partial x}+\frac{\partial(v C)}{\partial y} & =\frac{\partial}{\partial x}\left(K_{H} \frac{\partial C}{\partial x}\right) \\
& +\frac{\partial}{\partial y}\left(K_{H} \frac{\partial C}{\partial y}\right)-K_{M} C
\end{aligned}
$$

where

$x$ and $y$ are the horizontal distances in the east and north direction, respectively,

$u$ and $v$ are the depth-averaged velocities in the east $t$ is time, and north direction, respectively,

$C$ is the concentration of larval suckers,

$K_{M}$ is the mortality rate, and

$K_{H}$ is the horizontal turbulent diffusivity.

A spatially uniform value of $0.1 \mathrm{~m}^{2} / \mathrm{s}$ for $K_{H}$ was used in the larval density simulations presented in this report, corresponding to velocity and length scales of turbulence of $0.1 \mathrm{~cm} / \mathrm{s}$ and $100 \mathrm{~m}$, respectively.

According to Houde and Zastrow (1993), the mean mortality rate for the larval stage of marine fish is $K_{M}=0.24$, resulting in a loss of 21.3 percent of the population each day. For freshwater fish larvae, the rate is somewhat lower, at 14.8 percent each day, presumably because most of the species studied hatch from large eggs (Ware, 1975; Houde and Zastrow, 1993). A crude approximation of larval stage mortality rate $K_{M}$ also can be derived from growth rates $\left(K_{G}\right)$, using $K_{M}=1.217 * K_{G}-0.0131$ (Houde and Bartsch, 2009). Using the larval age and length data set from Markle and others (2009), the approximations are strongly size dependent, as expected (Houde and Bartsch, 2009). First-order estimates for sucker larvae by Markle and others (2009) were 8.2 percent each day for SNS/KLS suckers $\left(K_{M}=-0.0857 \mathrm{~d}^{-1}\right)$ and 2.6 percent each day for Lost River suckers $\left(K_{M}=-0.0262 \mathrm{~d}^{-1}\right)$. Given the variability in these mortality estimates, the sizedependent function of mortality, and the focus of this study on young larvae entering the lake, a somewhat higher $K_{M}$ of $0.1 \mathrm{~d}^{-1}$, corresponding to a loss of just over 10 percent of the population each day, was used.

The larval drift data collected in the Williamson River show that drift occurs at night, and that the larvae drop out of the flow, presumably holding position either near the bottom of the channel or at the sides of the channel during the day (Cooperman and Markle, 2003; Ellsworth and others, 2009). This behavior was incorporated into the larval density simulations as follows: At sunrise on each day, the larvae in each polygon of the Williamson River channel part of the numerical grid were removed. At sunset on each day, the same number of larvae that were removed from each Williamson River polygon on the previous sunrise was added back to that polygon. Any larvae that moved into the Williamson River polygons from the surrounding areas after sunrise were not stored and were transported normally throughout the day. The behavior was the same for both species.

The persistence (downstream distance or length of time) of this behavior - moving vertically or horizontally within the channel to escape the current during the day-is uncertain, and likely is age and (or) habitat dependent (Leis 2007; Gerlach and others, 2007; Wright and others, 2011). Three possible cases were considered: (1) The nighttime-only drift behavior was simulated through the entire Williamson River channel between the upstream boundary at Modoc Point Road and the mouth at Upper Klamath Lake, (2) The nighttime-only drift behavior was simulated in the Williamson River channel only upstream of the point where the channel enters the flooded land of the Delta (fig. 2), and (3) The nighttime-only drift behavior was assumed to occur only upstream of the Modoc Point Road boundary, and was not simulated in the channel within the domain of the numerical model.

\section{Comparison to Larval Catch Data}

Simulated larval densities were compared directly to larval catch data. Data from both randomly selected and fixed sites were included in this analysis. At each geographic location and time that a net measurement was made, the simulated density of larvae in the grid polygon associated with the site location (fig. 2), and at the time corresponding to the net catch, was paired with values of observed larval density in the net. For this purpose, replicate net measurements were averaged. Fish densities were not normally distributed, and a rank order correlation coefficient (Spearman $\rho$ ) was calculated for the paired data. Ties in the ranked data were assigned the same averaged rank. 

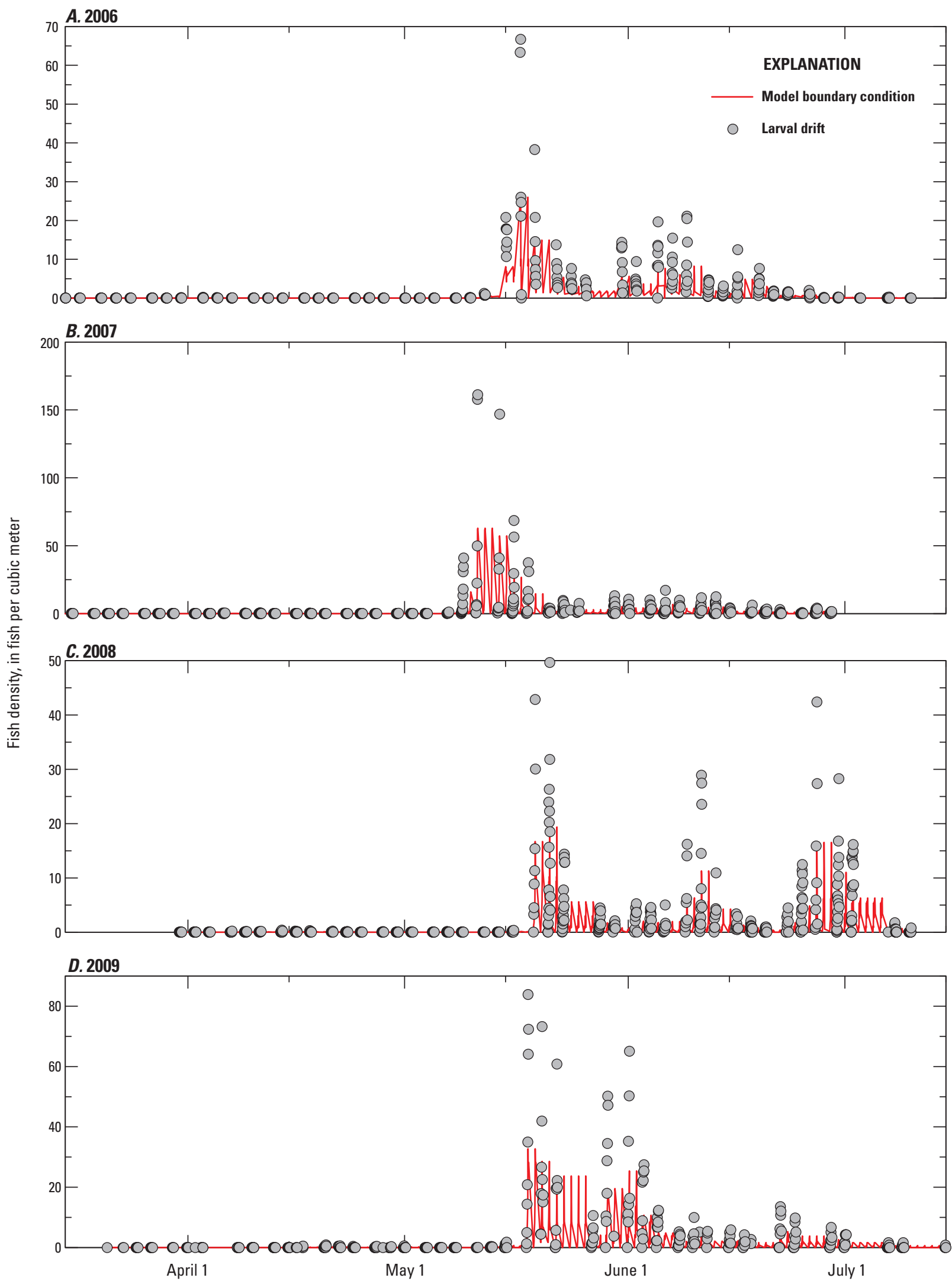

Figure 3. Measured larval drift and time series of the model boundary condition for fish density at the Modoc Point Road bridge, Upper Klamath Lake, Oregon, 2006-09. 
Correlations were calculated for the simulation period in each year by combining data collected in all gear types and by separating data collected in pop nets, larval trawls, and plankton nets. Additionally, the larval catches from each gear type were separated into small (10 to $13 \mathrm{~mm}$ ), mid (greater than 13 to $16 \mathrm{~mm}$ ), and large (greater than 16 to $19 \mathrm{~mm}$ ) sized fish, and the correlations were calculated for each size class. Using 2009 data only, the plankton net and larval trawl data were separated by species into LRS and SNS/KLS, and the correlations were calculated for each species. Finally, using 2009 data only, the correlations were calculated for each size class, with simulated data based on three assumptions regarding the spatial extent of Williamson River drift: throughout the channel from Modoc Point Road to the mouth, upstream of the Williamson River Delta only, and upstream of Modoc Point Road only.

\section{Response of Larval Transport to Changes in the Landscape at the Williamson River Delta}

Animations accompanying this report show the simulation of the tracer representing the total density of suckers (combination of LRS, SNS/KLS, and unidentified suckers) during 70 days in May through July, 2006 through 2009. Results from these simulations include:

- The larvae leave the Williamson River channel in "pulses" at night, the manifestation of the nighttimeonly drift along the entire length of the channel.

- In all years, the simulated larval aggregate tends to "hug" the eastern shoreline of Upper Klamath Lake, a manifestation of the clockwise circulation pattern that occurs under prevailing wind conditions from the west to northwest (fig. 4).

- All larvae in the simulation enter Upper Klamath Lake at the mouth of the Williamson River channel in 2006 and 2007, before the restoration at the Delta began.

- A strong wind reversal occurred in 2006 between May 21 and 24 (fig. 4A). This reversal caused the simulated larval aggregate to be advected northwest from the mouth of the Williamson River. The prevailing clockwise circulation reversed briefly, and the aggregate was advected in a counter-clockwise direction as far as the western shoreline. This reversal also resulted in larvae entering Agency Lake through Agency Straits.
- In 2008, after Tulana was flooded, but Goose Bay was still closed off from the Williamson River channel, the aggregate spread across Tulana and entered both Agency Lake and Upper Klamath Lake through breaks in the levees and over the levees that were submerged during this time.

- In 2009, after Goose Bay was flooded, strong prevailing winds tended to advect the simulated larval aggregate through Goose Bay in preference to Tulana, causing the centroid of the aggregate to enter Upper Klamath Lake through breaks in the levees and over the submerged levees on the south side of Goose Bay, which resulted in many larvae entering Upper Klamath Lake south of the mouth of the old Williamson River channel.

The changes in larval dispersal between 2006 and 2009 also can be seen in the time series of simulated densities at fixed larval catch sites (figs. 5, 7, $\underline{8}$ ). Simulated densities at site 25981 in Upper Klamath Lake near the mouth of the Williamson River channel, as well as at sites A and B in Tulana near the Williamson River channel (fig. 1), are shown in figure 5. Simulated densities within Tulana are available only for 2008 and 2009, after the restoration of the Delta started and the levees around Tulana were breached. Also shown is the simulated density at a point within the Williamson River channel (WR in fig. 5) about $1 \mathrm{~km}$ downstream of the Modoc Point Road boundary. This is not a fixed site for larval catches, but model output at the site is included to provide the larval density values in the channel before larvae enter the Delta. The simulated density at site 25981 decreased as a fraction of the simulated density upstream between 2006 and 2009. Between 2006 and 2007, this decrease is attributable to the higher flows in 2006 (fig. 6), which both decreased the larval travel time to Upper Klamath Lake, thus reducing accrued mortality in the river prior to entrance into the lake, and increased the momentum of the river flow, which pushed the larval aggregate farther into the lake. A large additional decrease in the density at site 25981 relative to the density upstream in 2008 and 2009 is a consequence of flooding first Tulana in 2008 and then Goose Bay in 2009. As a result, most of the larvae dispersed through Tulana in 2008 and the combined area of Tulana and Goose Bay in 2009 before reaching site 25981. The difference in travel time through the Delta between 2008 and 2009 can be seen in the simulated densities at sites A and B. In 2008, the densities at these two sites were similar, whereas in 2009, when Williamson River flows were lower, the greater travel time resulted in more accrued mortality between these two sites, and the simulated density at site B was lower than at site A (ig. 5). 
A.

Tulana Met Station [WMR MET] (422809121574800)

Data from U.S. Geological Survey, May 10, 2006 to July 20, 2006

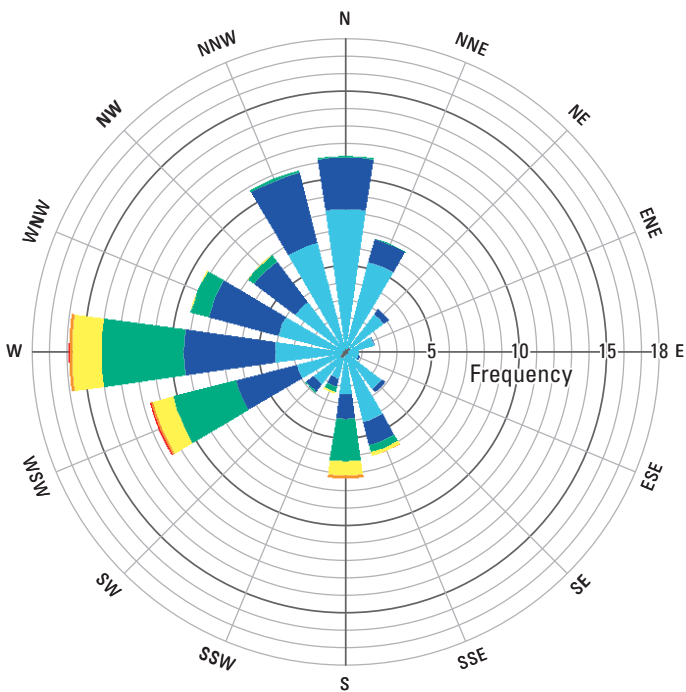

B.

Williamson Mouth East Met Stn [WME MET] (422801121572000) Data from U.S. Geological Survey, May 3, 2007 to July 13, 2007

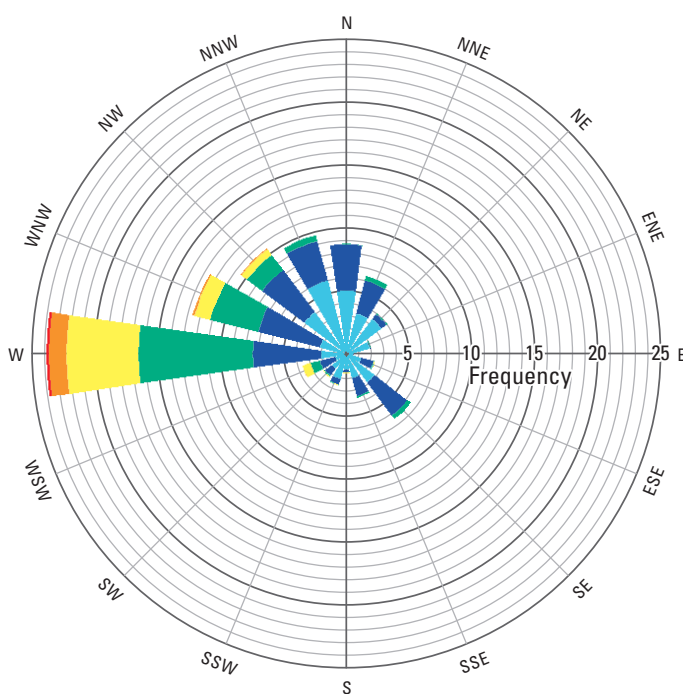

C.

Williamson River West Met Stn [WRW MET] (422807121572500) Data from U.S. Geological Survey, May 15, 2008 to July 25, 2008

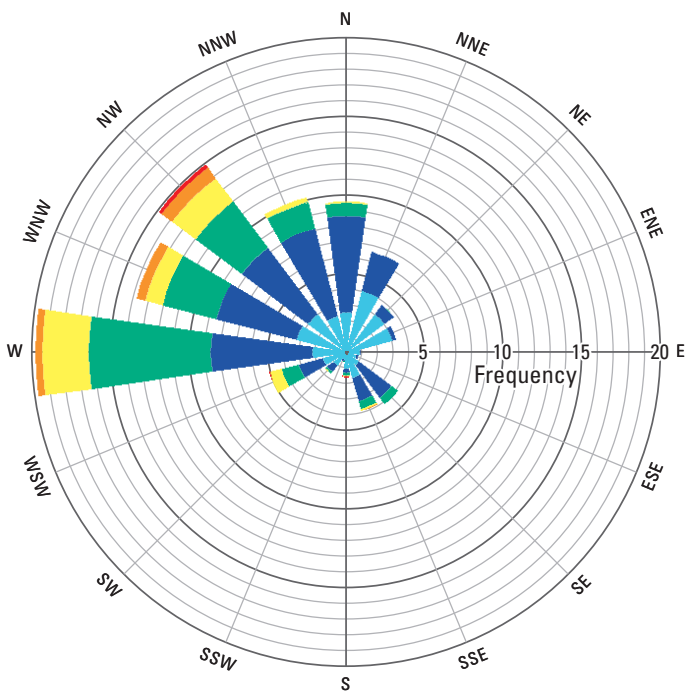

D.

Williamson River West Met Stn [WRW MET] (422807121572500) Data from U.S. Geological Survey, May 14, 2009 to July 24, 2009

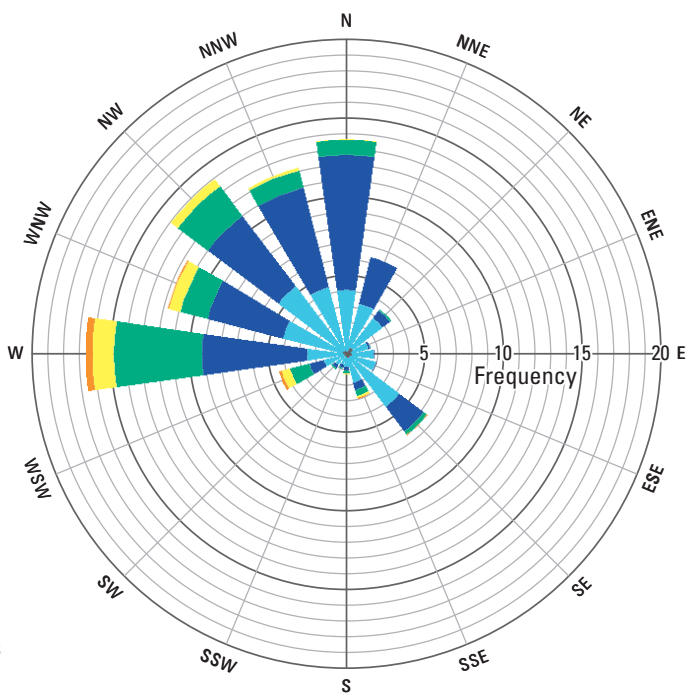

per second

EXPLANATION

Greater than 10

8 to 10

6 to 8

4 to 6

2 to 4

0.5 to 2

Less than 0.5

15 Frequency of time the wind

blew from each direction,

in percent

Figure 4. Wind direction and speed data collected at the Williamson River Delta, Upper Klamath Lake, Oregon. (A) May 10July 20, 2006; (B) May 3-July 13, 2007; (C) May 15-July 25, 2008; and (D) May 14-July 24, 2009. 
A. 2006
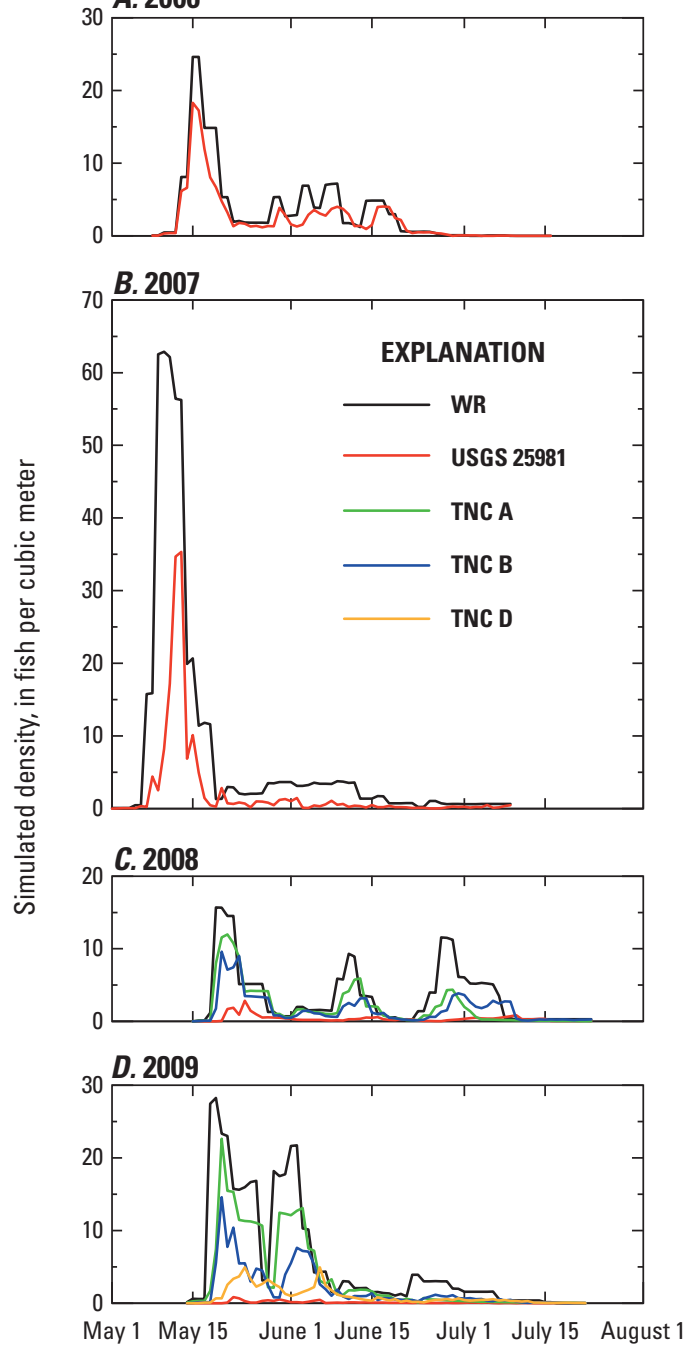

Figure 5. Simulated density of larval suckers at larval catch sites (except WR) in the Williamson River Delta, Oregon, 2006-09. WR is a location in the Williamson River approximately $1 \mathrm{~km}$ downstream of the Modoc Point Road bridge. The daily maximum at each site is shown.
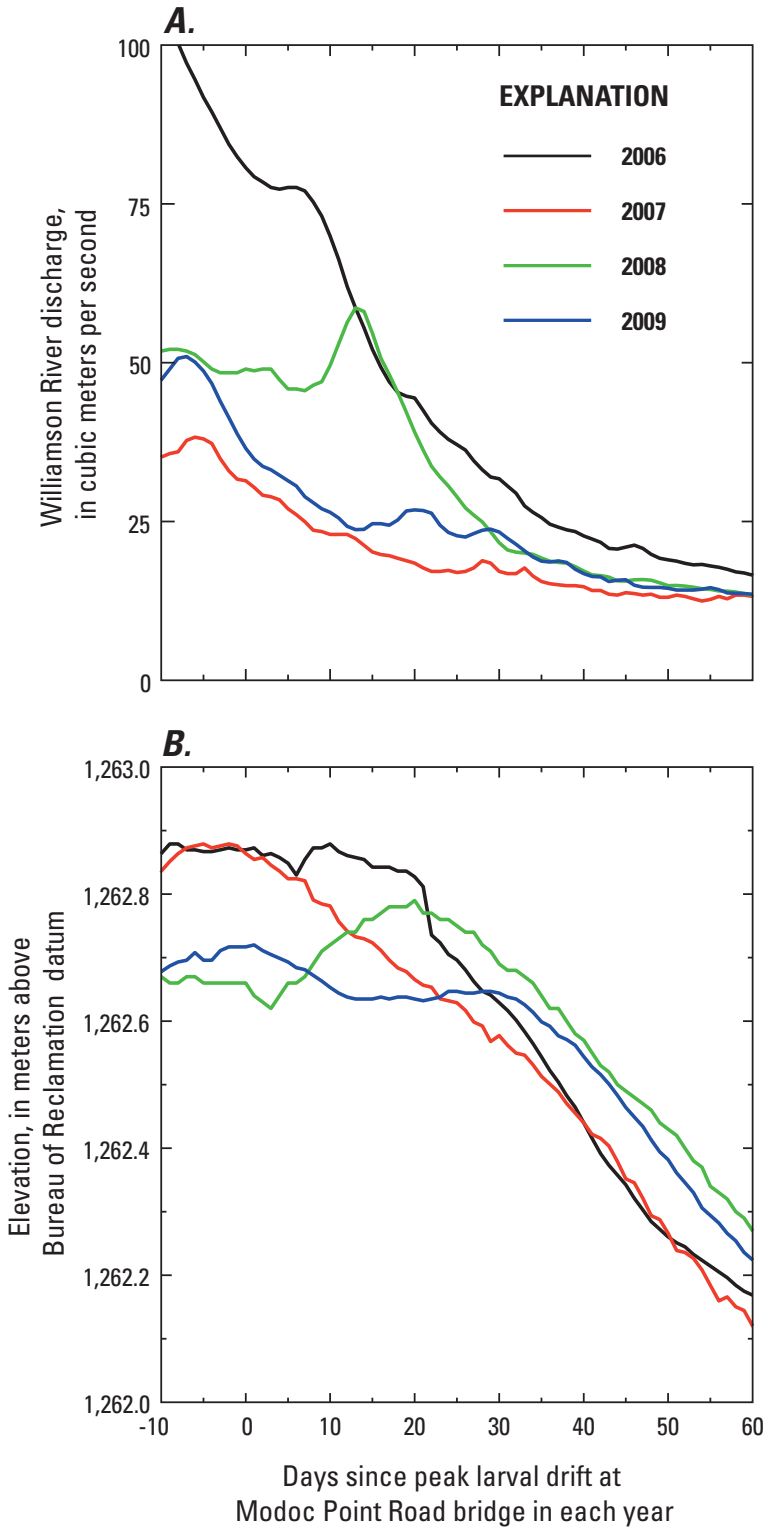

Figure 6. (A) Discharge of Williamson River and $(B)$ elevation of Upper Klamath Lake, Oregon, between May and July 2006-09. 
The time series of the simulated daily maximum density at selected fixed sites along the shoreline in Upper Klamath Lake are shown in figure 7. Site U6 is located on the south side of the Williamson River channel near its mouth. To the east and south of the mouth along the shoreline are sites U5 and U4. To the west and north of the Williamson River mouth are sites 25976 and 25977 (fig. 1). The simulated densities at site U6 and the relation of those densities to the upstream densities in the Williamson River are similar to those at site 25981. Of note in figure 7 is the relation of simulated densities at sites to the northwest and southeast to densities at site U6. In 2006-08, there is a decrease in density from sites U6 to $\mathrm{U} 5$ to $\mathrm{U} 4$, in the prevailing direction of transport of the larval aggregate along the shoreline, reflecting the increasing travel time along this pathway, and therefore increasing dispersal and mortality along the pathway as well. Sites northwest of the Williamson River mouth are in the direction opposite to the prevailing transport; thus, in 2007, simulated densities at sites 25977 and 25976 were lower than densities at sites U6, U5, and U4. In 2006, simulated densities at site 25976 were comparable to densities at site U5, a consequence of the large wind reversal in 2006 that pushed the aggregate of larvae northward for a few days around May 21.

After Tulana was flooded, larvae moving into the Delta could exit at two levee breaches along the Upper Klamath Lake shoreline, approximately opposite sites 25977 and 25976. These new pathways resulted in higher concentrations at these two sites relative to the Williamson River channel, than prior to the start of restoration. Of particular note is the change in the simulated densities at site U5 between 2008 and 2009. In 2009, after Goose Bay was flooded, the simulated densities at sites along the Upper Klamath Lake shoreline were highest at site U5, and lower both to the southeast at site U4, and to the northwest at sites U6, 25977, and 25976. The configuration of the landscape prior to 2008 forced virtually all the larvae to exit the Delta at the mouth of the Williamson River, which is manifested as proportionately higher densities at site U6 in those years. When Tulana was flooded, proportionately fewer larvae exited at the old mouth of the Williamson River as larvae were dispersed throughout Tulana and exited through breaches into Upper Klamath Lake and, to a lesser extent, Agency Lake. In 2009, after Goose Bay was flooded, most of the simulated larvae that exited the Delta to Upper Klamath Lake did not do so at the mouth, but through the open levees on the Goose Bay side of the Delta.
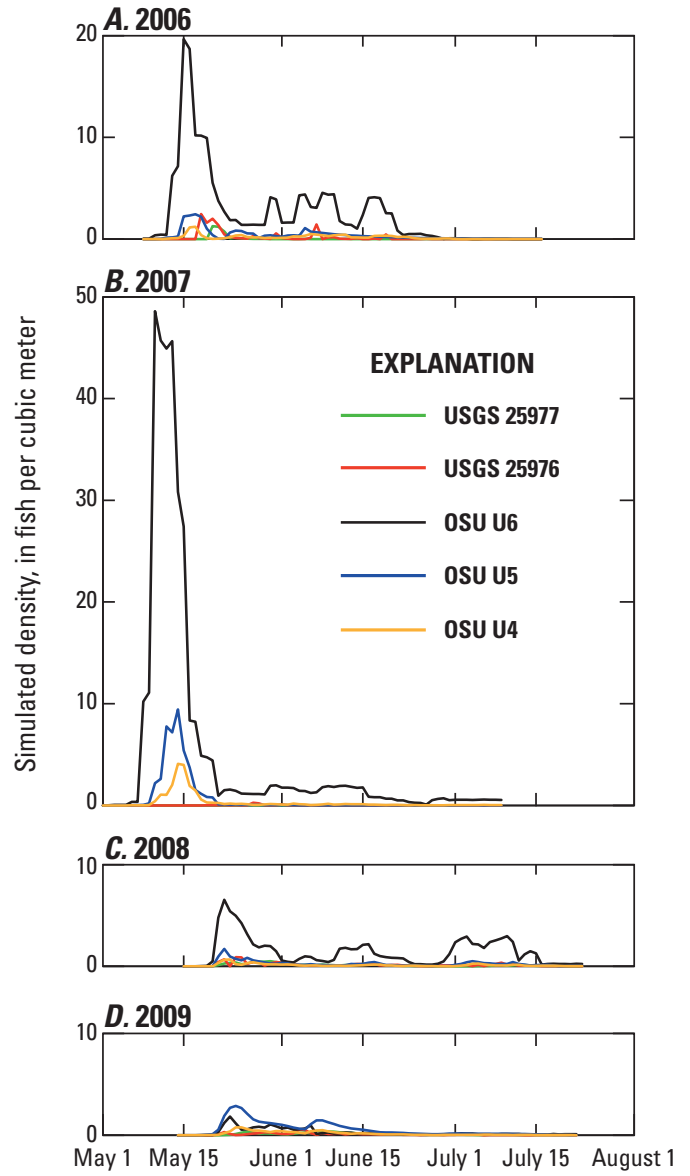

Figure 7. Simulated density of larval suckers at larval catch sites in Upper Klamath Lake, Oregon, 2006-09. The daily maximum at each site is shown. 
Four sites are located on the northern side of the Delta in Agency Lake_-sites 25978, 25979, A1, and A2 (ig. 8). Site A1 was outside of the numerical grid used for 2006 and 2007 simulations. Few simulated larvae ended up in Agency Lake prior to the restoration of the Williamson River Delta, even though simulated densities were approximately an order of magnitude higher in 2006 than in 2007 because of the strong wind reversal in 2006 that carried the aggregate of larvae northward from the river mouth. In the 2008 configuration of the landscape, more larvae passed through Tulana and through breaches on the northern levees surrounding Tulana to end up in Agency Lake, even though the peak densities there were lower than in Upper Klamath Lake, even at sites located near the openings in the levees (sites 225978 and 25979). Generally lower densities in Agency Lake in 2009 are a consequence of larval dispersal over the combined area of Tulana and Goose Bay, and the preferential exiting of the larvae on the Upper Klamath Lake side of the Delta under prevailing wind conditions.

One fixed site (U8, simulated densities not shown) is located on the western side of Upper Klamath Lake. Simulated densities this far from the source at the Williamson River were low; peak densities were $0.18,0.15,0.03$, and 0.02 fish per cubic meter in 2006 to 2009, respectively. The simulations showed that densities at site U8 decreased markedly in 2008, after the flooding of Tulana, because the larval aggregate was forced farther out into the lake in 2006 and 2007, and more of the larvae were entrained in the clockwise circulation gyre and carried to the western side of the lake.

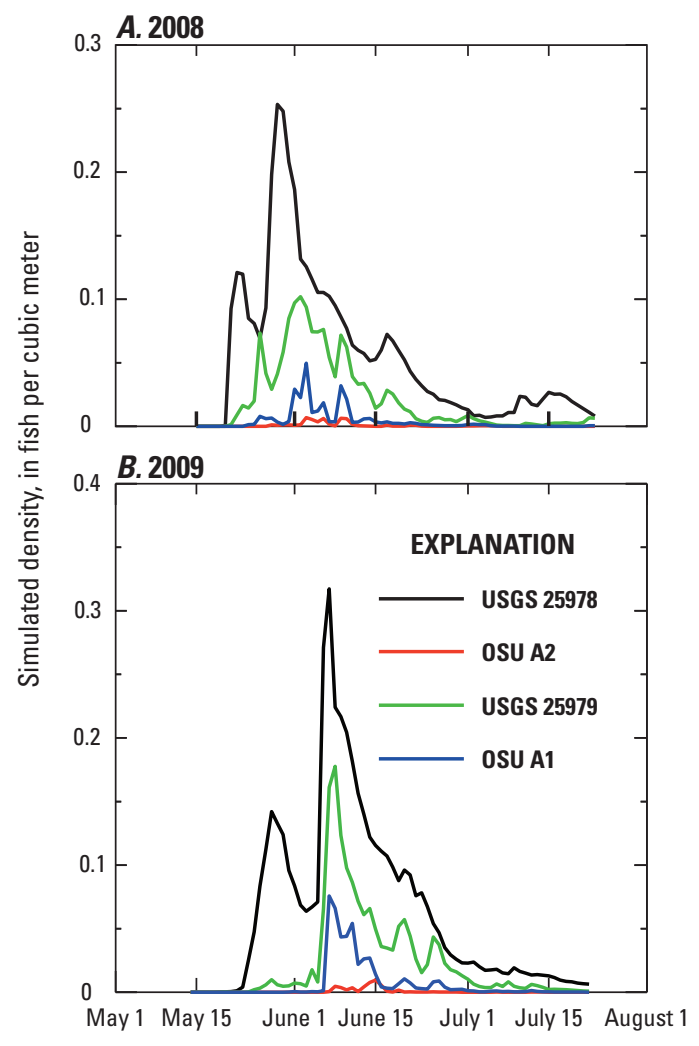

Figure 8. Simulated density of larval suckers at larval catch sites in Agency Lake, Oregon, 2008-09. The daily maximum at each site is shown. 


\section{Implications of Drift Behavior for Daytime Densities}

Sites close to the Modoc Point Road boundary and the Williamson River channel showed a strong diel cycle in simulated density. At some sites, different assumed drift behaviors had a marked effect on that diel cycle. Site A (fig. 9) is within about a one-half day of travel time from the Modoc Point Road boundary and within a few hours travel time from the Williamson River channel. If larval drift was assumed to occur only at night throughout the length of the Williamson
River channel, then simulated larval densities at that site reflected the same day-night cycle, such that maximum densities were simulated at night. This held true if the nighttime-only drift behavior was assumed to be limited to that part of the channel upstream of the Delta. If instead nighttimeonly larval drift occurred upstream but not downstream of the Modoc Point Road boundary, then the maximum simulated densities at site A occurred during the day. Site B is located several hours travel time farther from the Williamson River channel, and simulated concentrations there tended to be a maximum during daylight hours, regardless of the assumed drift behavior in the Williamson River channel (fig. 10).

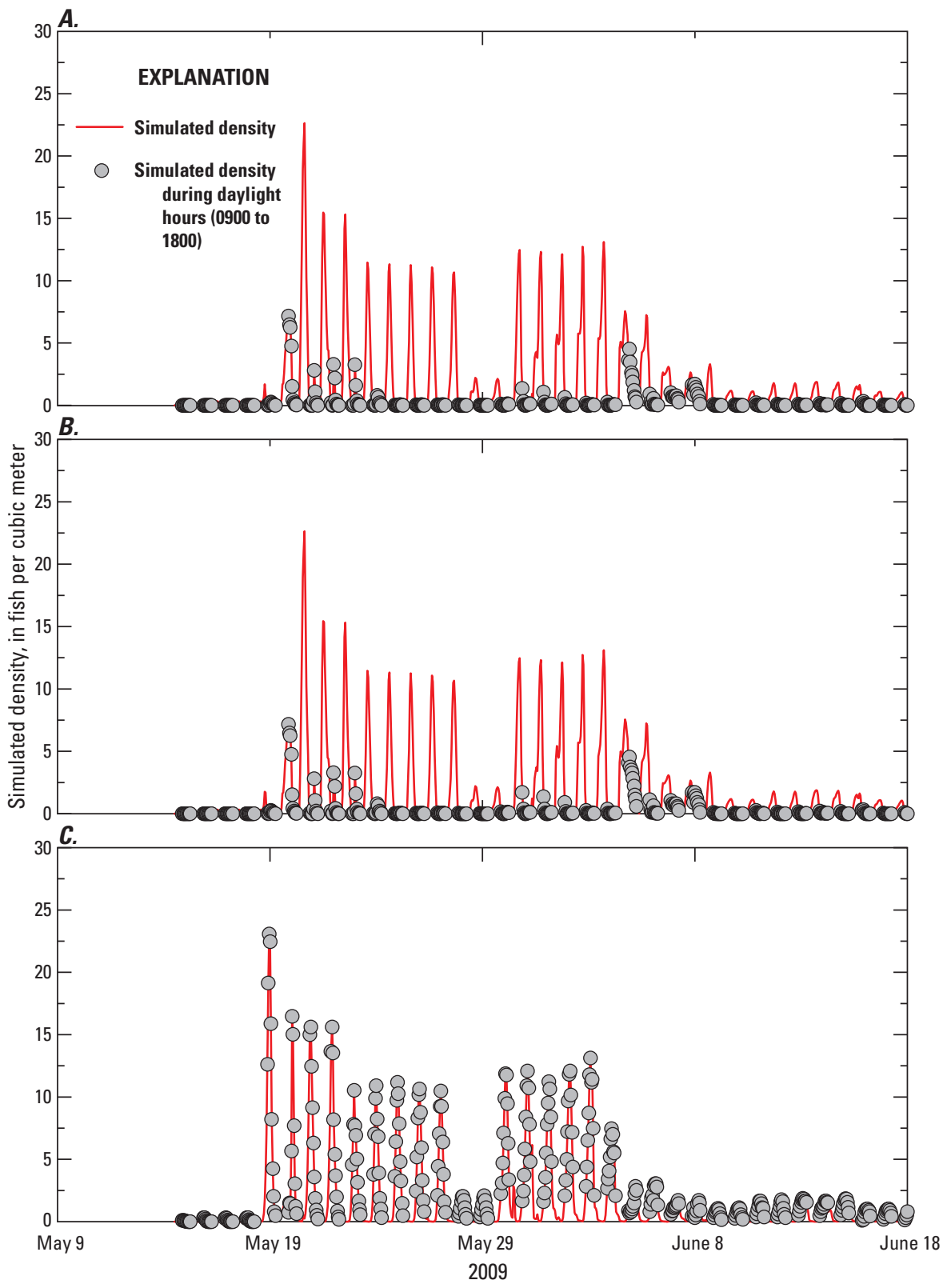

Figure 9. Simulated density of larval suckers at site A, Williamson River Delta, Oregon. (A) Larval drift only at night throughout the Williamson River channel, $(B)$ larval drift only at night in the Williamson River channel upstream of the Delta, and $(C)$ larval drift only at night in the Williamson River channel upstream of the Modoc Point Road bridge. 


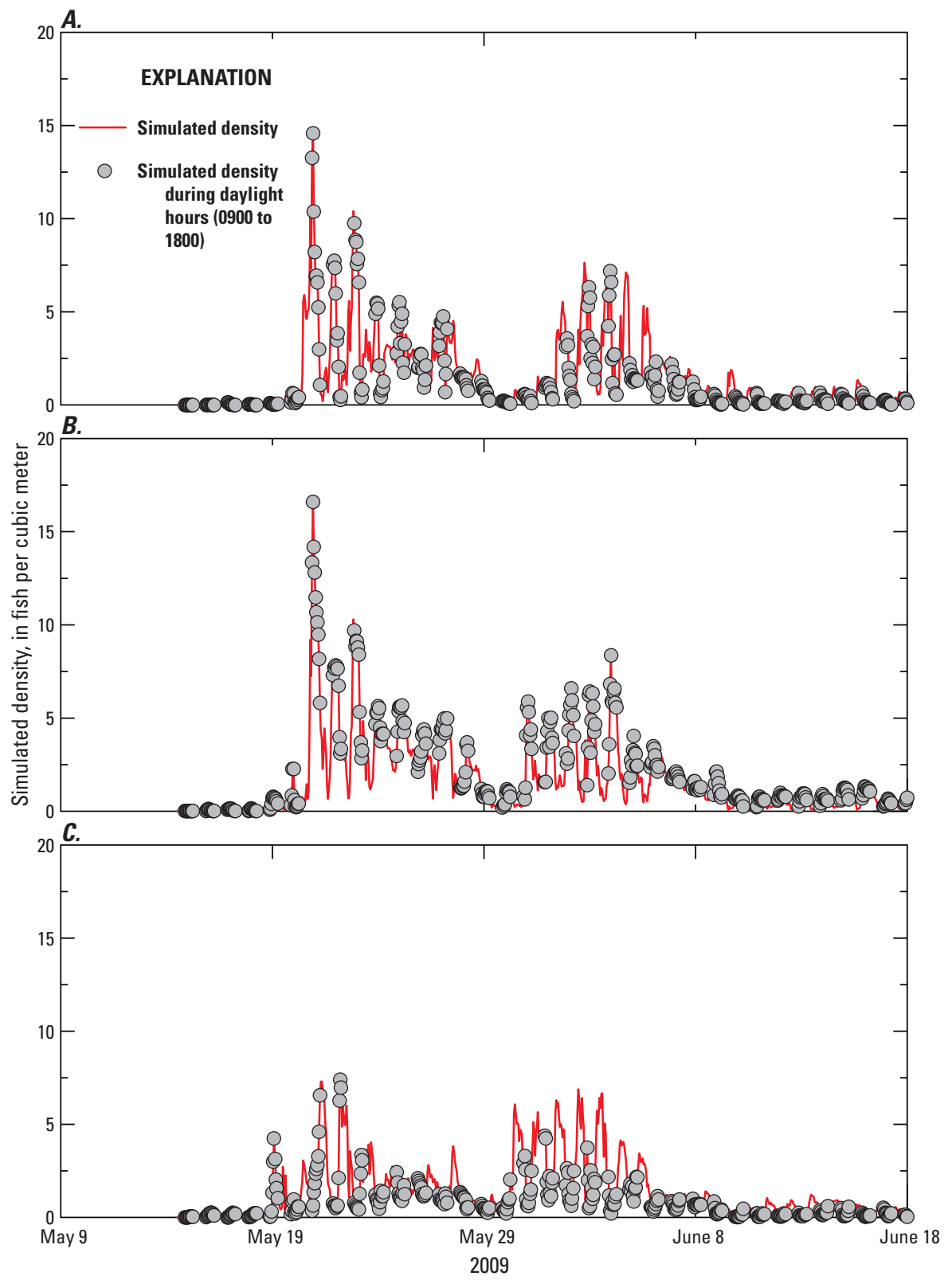

Figure 10. Simulated density of larval suckers at site B, Williamson River Delta, Oregon. (A) Larval drift only at night throughout the Williamson River channel, $(B)$ larval drift only at night in the Williamson River channel upstream of the Delta, and (C) larval drift only at night in the Williamson River channel upstream of the Modoc Point Road bridge. 
Farther from the channel, in Goose Bay, the extent of larval drift in the channel was manifested as a varying strength of the diel cycle in the simulated density at site D (fig. 11). When nighttime-only drift behavior was assumed to persist throughout the channel, a large diel cycle was simulated at this site, but when nighttime-only drift behavior was assumed to occur only upstream of the Delta or upstream of the Modoc Point Road boundary, the diel cycle at this site was diminished. At sites located in Tulana (site 25980) and at the mouth of the Williamson River (site 25981), the difference in assumptions about nighttime-only drift behavior is not discernible in the simulated densities (not shown).

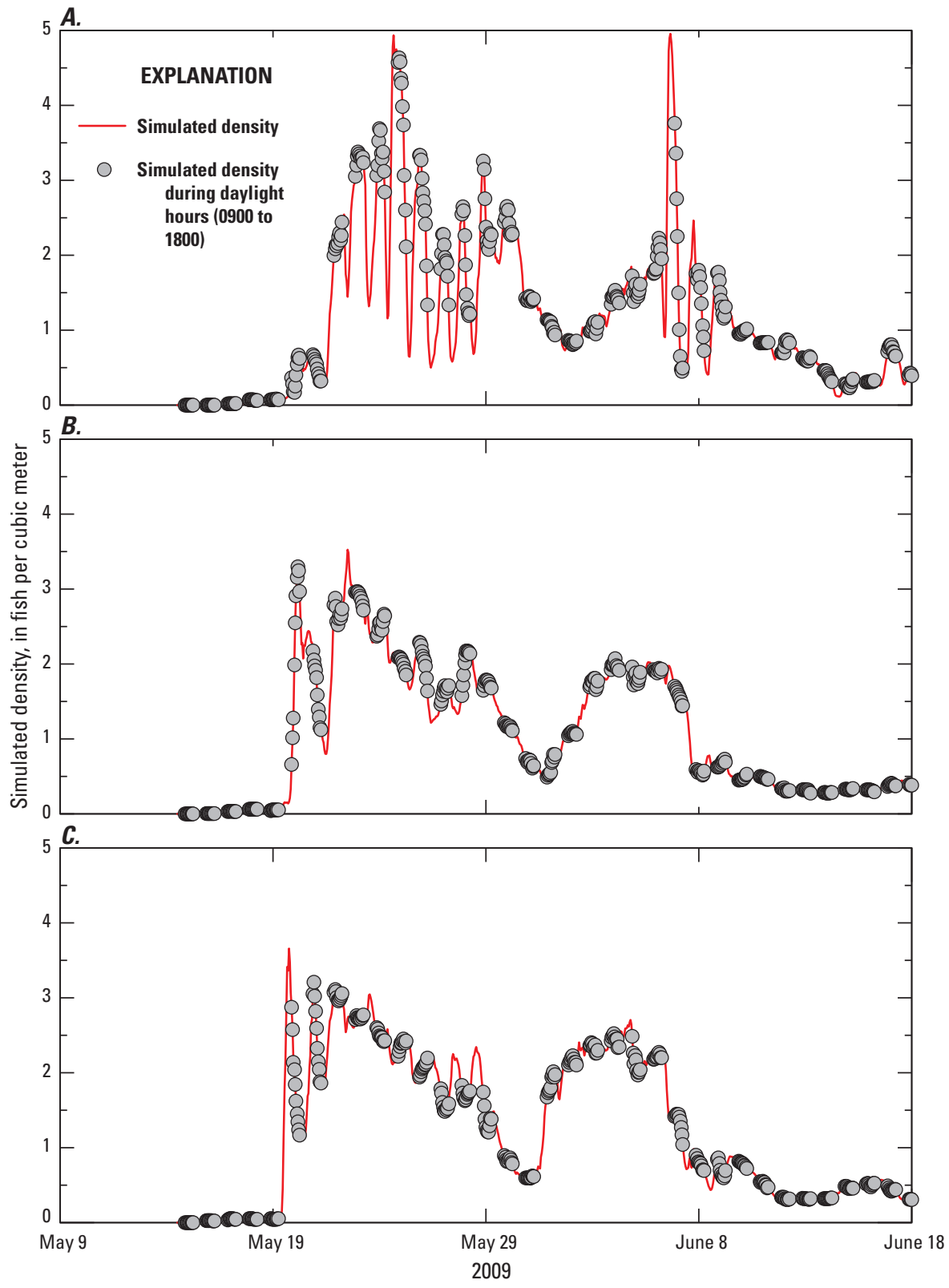

Figure 11. Simulated density of larval suckers at site D, Williamson River Delta, Oregon. (A) Larval drift only at night throughout the Williamson River channel, $(B)$ larval drift only at night in the Williamson River channel upstream of the Delta, and $(C)$ larval drift only at night in the Williamson River channel upstream of the Modoc Point Road bridge. 


\section{Correlation of Simulated Densities to Larval Catch Data}

Correlations between simulated densities and the corresponding larval catch densities at all of the sites were almost always positive, often significant, but uniformly low, indicating that the simulated densities captured the general pattern of distributions but were poor predictors of larval catch densities in individual nets (table 2). The way that the correlations vary among gear types and species, however, suggests some gear-specific differences with regard to size class and species.

The smallest size class of fish caught in pop nets was most highly correlated with simulated densities (correlation coefficients ranged from 0.88 in 2006 to 0.27 in 2009), and the largest size class of fish caught in pop nets was least correlated with simulated densities (the sign of the correlation coefficients was mixed, and the correlation coefficient was positive and significant only in 2008 , at 0.24 ). In contrast, the middle size class of fish caught in larval trawls was most highly correlated with simulated densities (correlation coefficients ranged from 0.49 in 2006 to 0.57 in 2009), and the smallest size class caught in larval trawls was least highly correlated with simulated densities (correlation coefficients ranged from 0.56 in 2007 to 0.20 in 2009). The largest size class of fish caught in larval trawls was not correlated $(p<0.05)$ with the simulated densities, but the correlation coefficients were all positive and ranged from 0.29 in 2007 to 0.23 in 2009. The smallest size class of fish caught in plankton nets was significantly correlated with simulated densities in 2008 and 2009 (correlation coefficient 0.21 in 2008 and 0.25 in 2009, $p<0.05$ ), but the middle size class caught in plankton nets was correlated with simulated densities only in 2009; and in 2008, the only year when the largest size class of fish was caught in plankton nets, the catch was not correlated with simulated density $(p<0.05)$.

When the 2009 larval catches were separated by species and the two species were modeled separately, the plankton net data were significantly correlated with the simulated densities of SNS/KLS suckers (correlation coefficient 0.22, $p<0.05$ ), but not with simulated densities of LRS. The larval trawl data were correlated approximately equally with simulated densities of SNS/KLS suckers and with LRS suckers (correlation coefficients 0.48 and 0.42 , respectively; $p<0.05$ ). The pop net data were more highly correlated with the simulated densities for LRS suckers than for SNS/ KLS suckers, although both correlations were significant (correlation coefficients 0.34 and 0.20 , respectively; $p<0.05$ ).
Pop net correlations were somewhat higher for small sized fish when nighttime-only drift was assumed to occur only upstream of the Modoc Point Road boundary, but plankton net and larval trawl correlations in 2009 did not change much based on the assumed extent of nighttime-only drift.

\section{Discussion}

The model simulation results showed that aggregations of passively transported larvae coming down the Williamson River were dispersed over a larger area in 2008, after the flooding of Tulana, than in prior years when those aggregates were constrained by the Williamson River channel from spawning grounds to the mouth of the river at Upper Klamath Lake. In 2009, after Goose Bay was flooded, the larvae dispersed over an even larger area. Two of the three agencies involved in this study sampled larvae in each year from 2006 to 2009, and among these 4 years, the larval catches in both gear types (larval trawls and pop nets) were greatest in 2006 and least in 2009 (figs. 12-14; table 3). The USGS collected data from plankton nets only in 2008 and 2009; catches at most sites were lower in 2009 than in 2008. These results are broadly consistent with passive transport of the larvae as demonstrated by the modeling exercise. With the restoration of the Delta, the larval aggregate dispersed through the newly flooded areas, and remnants of the aggregate entered Upper Klamath Lake through multiple pathways. This resulted in lower simulated densities of fish at net locations along the shorelines of Upper Klamath and Agency Lakes.

Evidence for the simulated changes in the number of larvae entering Upper Klamath Lake at the mouth of the Williamson River between 2006 and 2009 can be found in the pop net data collected along the Upper Klamath Lake side of the levees that formed the southern boundary of Goose Bay. Pop net data were collected along these levees from 2006 to 2009 (fig. 2). At these pop net sites, there was a decrease in the catch of larval suckers in 2009 after the restoration of Goose Bay was complete (Erdman and Hendrixson, 2010). This was the first year that the annual mean catch per unit effort (CPUE) at these pop net sites was less than in nets in the restored wetlands, which included Tulana and Goose Bay (Erdman and Hendrixson, 2010). The lower CPUE at the pop net sites in Upper Klamath Lake is consistent with the model simulation results showing fewer larvae entering Upper Klamath Lake at or north of the Williamson River mouth, then being transported southeastward along the Upper Klamath Lake side of the levees. 
Table 2. Spearman correlation coefficients between the density of larval suckers captured at larval catch sites and the simulated density at each site, Upper Klamath and Agency Lakes, Oregon, 2006-09.

[Behavior indicates that simulated densities were obtained assuming (a) nighttime-only larval drift in the Williamson River channel from Modoc Point Road bridge to the mouth, (b) nighttime-only larval drift upstream of the Williamson River Delta, or (c) nighttime-only larval drift upstream of the Modoc Point Road bridge. Small: fish sized 10-13 mm; M id, fish sized $>13-16 \mathrm{~mm}$; L arge, fish sized $>16-19 \mathrm{~mm}$. Boldface type indicates that the number of samples (N) was less than 75 , and correlation was significant $(p<0.05)$. Boldface italicized type indicates that the number of samples $(\mathrm{N})$ was greater than 75 , and correlation was significant $(p<0.05)$. A bbreviations: $>$, greater than; $<$, less than; LRS, Lost River sucker; SNS, grouping of shortnose and Klamath largescale suckers; mm, millimeter; /, no larval catch data; -, no simulated data]

\begin{tabular}{|c|c|c|c|c|c|c|c|}
\hline \multirow{2}{*}{ Year } & \multirow{2}{*}{ Behavior } & \multirow{2}{*}{$\begin{array}{c}\text { Total } \\
\text { density }\end{array}$} & \multicolumn{3}{|c|}{ Density } & \multirow{2}{*}{$\begin{array}{c}\text { LRS } \\
\text { density }\end{array}$} & \multirow{2}{*}{$\begin{array}{l}\text { SNS } \\
\text { density }\end{array}$} \\
\hline & & & Small & Mid & Large & & \\
\hline \multicolumn{8}{|c|}{ All data combined } \\
\hline 2006-09 & a & 0.19 & 0.19 & 0.18 & 0.00 & - & - \\
\hline 2006 & a & 0.55 & 0.56 & 0.57 & 0.29 & - & - \\
\hline 2007 & a & 0.46 & 0.52 & 0.40 & 0.21 & - & - \\
\hline 2008 & a & 0.27 & 0.24 & 0.26 & 0.15 & - & - \\
\hline 2009 & a & 0.29 & 0.24 & 0.29 & 0.02 & 0.22 & 0.26 \\
\hline 2009 & b & 0.32 & 0.25 & 0.31 & 0.05 & - & - \\
\hline 2009 & c & 0.35 & 0.29 & 0.33 & 0.03 & - & - \\
\hline \multicolumn{8}{|c|}{ Plankton net data only } \\
\hline 2008 & a & 0.23 & 0.21 & 0.14 & 0.02 & - & - \\
\hline 2009 & a & 0.28 & 0.25 & 0.23 & I & 0.07 & 0.22 \\
\hline 2009 & b & 0.30 & 0.26 & 0.26 & I & - & - \\
\hline 2009 & c & 0.26 & 0.21 & 0.22 & I & - & - \\
\hline \multicolumn{8}{|c|}{ Larval trawl data only } \\
\hline 2006 & a & 0.39 & 0.22 & 0.49 & 0.28 & - & - \\
\hline 2007 & a & 0.59 & 0.56 & 0.53 & 0.29 & - & - \\
\hline 2008 & a & 0.40 & 0.36 & 0.52 & 0.26 & - & - \\
\hline 2009 & a & 0.53 & 0.20 & 0.57 & 0.35 & 0.42 & 0.48 \\
\hline 2009 & b & 0.55 & 0.23 & 0.58 & 0.37 & - & - \\
\hline 2009 & c & 0.56 & 0.27 & 0.57 & 0.34 & - & - \\
\hline \multicolumn{8}{|c|}{ Pop net data only } \\
\hline 2006 & a & 0.76 & 0.88 & 0.63 & 0.28 & - & - \\
\hline 2007 & a & 0.22 & 0.43 & 0.13 & -0.03 & - & - \\
\hline 2008 & a & 0.39 & 0.33 & 0.30 & 0.24 & - & - \\
\hline 2009 & a & 0.05 & 0.27 & 0.12 & -0.19 & 0.34 & 0.20 \\
\hline 2009 & b & 0.08 & 0.30 & 0.13 & -0.17 & - & - \\
\hline 2009 & c & 0.12 & 0.40 & 0.14 & -0.25 & - & - \\
\hline
\end{tabular}



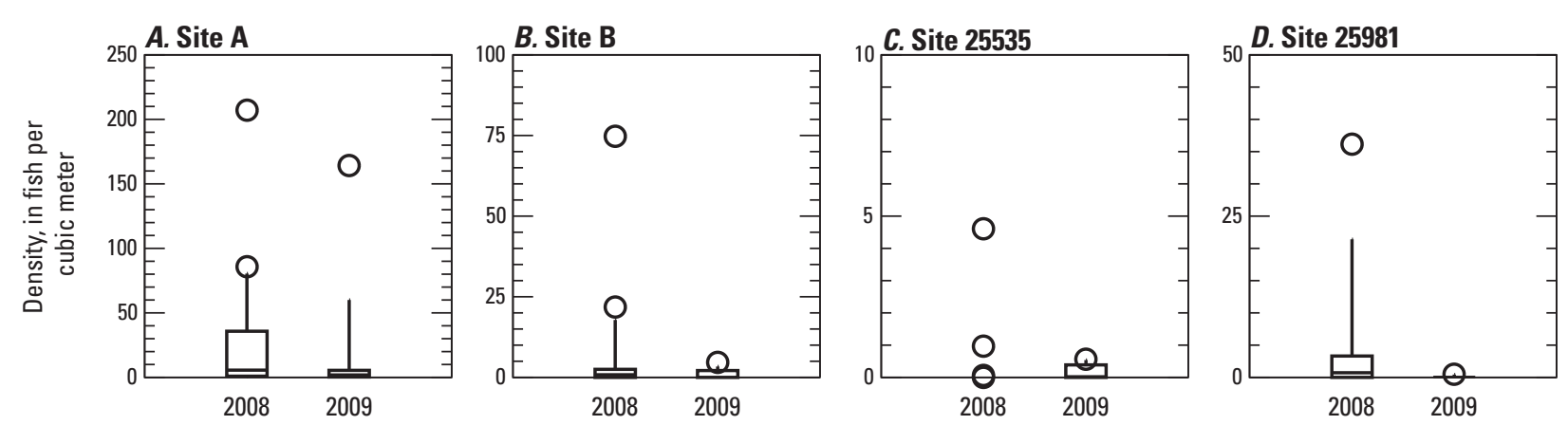

EXPLANATION

Outlier

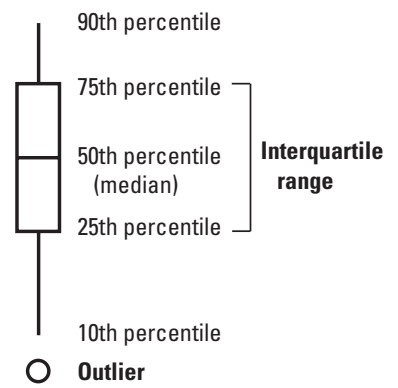

Figure 12. Catch density of larval suckers at sites in the Williamson River Delta and at the mouth of the Williamson River, Oregon, 2006-09.
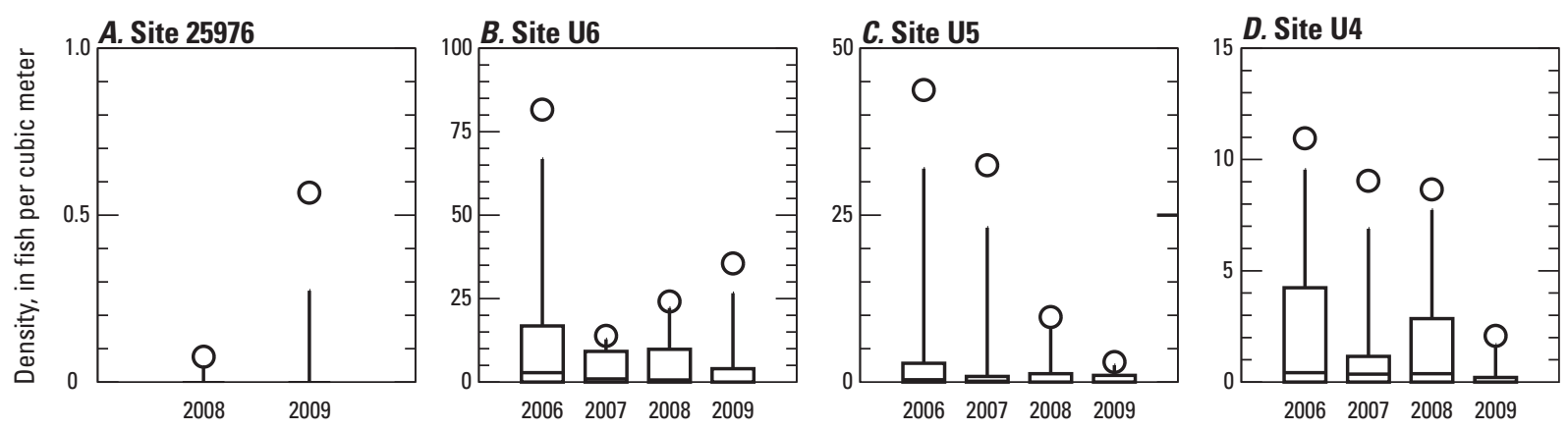

EXPLANATION

O Outlier

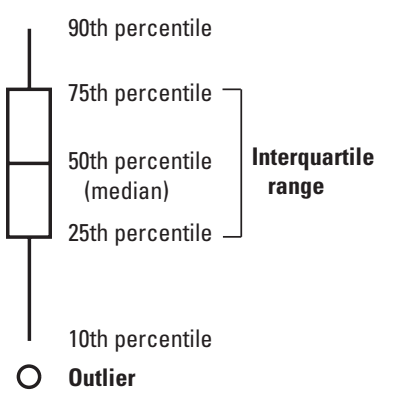

Figure 13. Catch density of larval suckers at sites in Upper Klamath Lake, Oregon, 2006-09. 

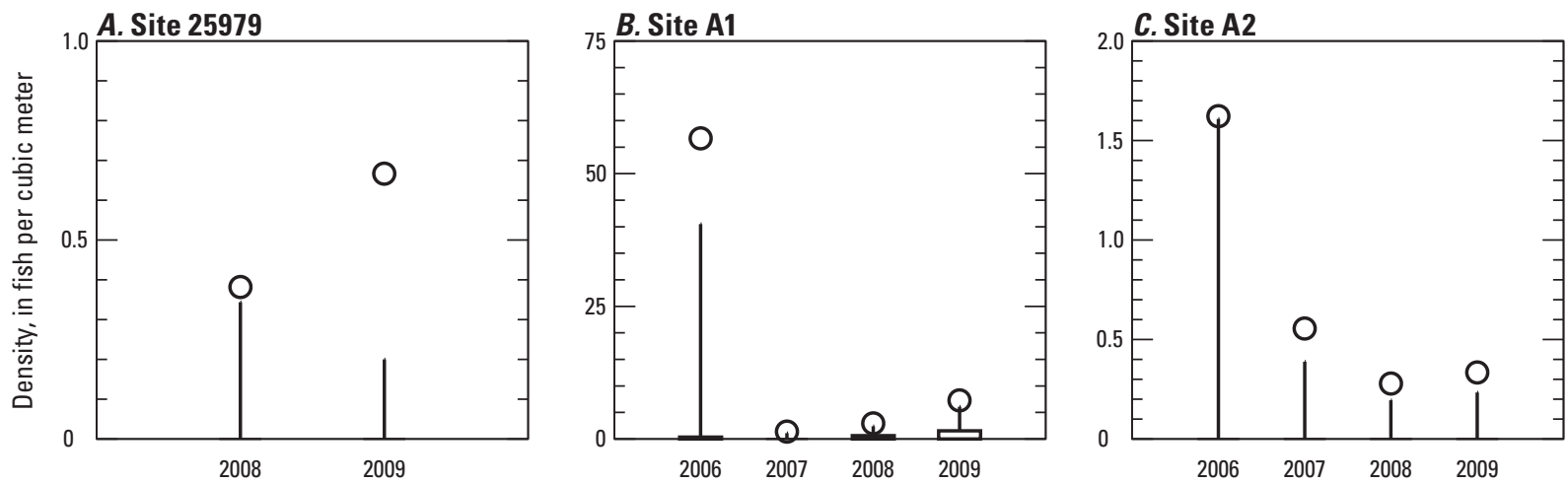

\section{EXPLANATION}

O Outlier

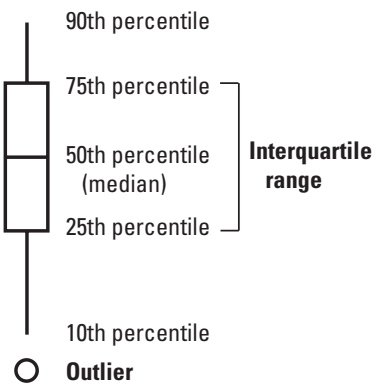

Figure 14 Catch density of larval suckers at sites in Agency Lake, Oregon, 2006-09.

Table 3. Characteristics of the net catches in the drift at Modoc Point Road bridge and for three different gear types, Upper Klamath Lake, Oregon, 2006-09.

[Relative numbers of LRS and SNS in the drift determined with a Wilcoxon test $(p<0.05)$. Abbreviations: CPUE, catch per unit effort; LRS, Lost River sucker; SNS, grouping of shortnose and Klamath largescale suckers; $\mathrm{m}^{3}$, cubic meter; >, greater than; <, less than; $\sim$, not different from]

\begin{tabular}{|c|c|c|c|c|c|c|c|c|c|}
\hline Year & $\begin{array}{c}\text { Restoration } \\
\text { status }\end{array}$ & \multicolumn{2}{|c|}{ Modoc Point Road bridge ${ }^{1}$} & \multicolumn{2}{|c|}{ Pop nets ${ }^{2}$} & \multicolumn{2}{|c|}{ Larval trawls ${ }^{3}$} & \multicolumn{2}{|c|}{ Plankton nets ${ }^{4}$} \\
\hline 2006 & Levees intact & 2.57 & $\mathrm{LRS} \sim \mathrm{SNS}$ & 20.2 & 37 & 13.5 & 26.2 & & \\
\hline 2007 & Levees intact & 3.69 & LRS $>$ SNS & 9 & 23 & 4.6 & 8.1 & & \\
\hline${ }^{3} 2009$ & $\begin{array}{l}\text { Levees around breached } \\
\text { Goose Bay }\end{array}$ & 6.86 & LRS $>$ SNS & 3.95 & 11 & 2.5 & 28.9 & 0.004 & 0.06 \\
\hline
\end{tabular}

${ }^{1} 2006$ and 2007 larval drift data from Ellsworth and others, 2009; 2008 larval drift data from Ellsworth and others, 2011; 2009 larval drift data from unpublished results.

${ }^{2} 2006$ and 2007 pop net data from Hendrixson, 2008; 2008 pop net data from Erdman and Hendrixson, 2009; 2009 pop net data from Erdman and Hendrixson, 2010.

${ }^{3} 2008$ plankton net data from Burdick and others, 2009; 2009 plankton net data from Burdick and Brown, 2010.

${ }^{4}$ Larval trawl data from unpublished results. 
There was a large decrease in the mean CPUE in pop nets and larval trawls between 2006 and 2007, however, which was not a result of a change in the landscape, and only a small decrease between 2007 and 2008, when a large change in the landscape occurred with the flooding of Tulana (table 3). This was likely because the annual mean CPUE catch statistics reflect not only the changes in the landscape as the Delta underwent restoration, but also the interannual differences in the number and species composition of larvae. Different total densities and different relative numbers of LRS and SNS/KLS sucker larvae were observed in the drift at the Modoc Point Road bridge during the 4 years of this study (table 3). In 2006 and 2008, the second (and third, in 2008) pulses of larvae (dominated by SNS/KLS) were comparable in size to the first pulses dominated by LRS larvae (fig. 3); the difference in the density of the two species in the net catches at the Modoc Point Road bridge was not statistically significant in 2006, and in 2007 and 2009 the density of LRS was greater (Wilcoxon test, $p<0.05$ ). In 2008, however, the density of SNS/KLS was greater (Wilcoxon test, $p<0.05$ ). These drift data provide the upstream boundary condition for the model simulations, and because no species-specific differences in transport or mortality are included in the model, the simulated densities downstream of all species combined are influenced by the individual species in proportion to their occurrence in the drift. However, the statistics of species distribution in the various gear types tell a different story. Pop nets and larval trawl nets consistently captured more SNS/KLS larvae than LRS larvae, even in years when the drift of LRS from spawning sites was comparable to or greater than the drift of SNS/KLS. Therefore, the large decrease in mean CPUE at these sites between 2006 and 2007, which was not simulated by the model, could be due to the drift being dominated by LRS in 2007, and LRS not being captured as effectively by the gear. In 2008, the drift was dominated by $\mathrm{SNS} / \mathrm{KLS}$, and so the greater dispersal of larvae due to the opening of Tulana could have been compensated to some extent by the greater efficiency of the gear in capturing the dominant species. In contrast to the pop net data, in 2008, 81 percent of the suckers caught in the plankton nets and identified to species were LRS (Burdick and others, 2009; table 3). The reverse distribution was seen in 2009, when 90 percent of the identified suckers were SNS/KLS (Burdick and Brown, 2010; table 3). The plankton nets captured large numbers of LRS in 2008, but the mean density of this species in plankton nets decreased by two orders of magnitude in 2009, even though more LRS came down the Williamson River in the drift in 2009 and the number of SNS/KLS captured in plankton nets remained roughly the same (table 3). These sites are located primarily in Tulana and in Upper Klamath and Agency Lakes, and north of the Williamson River mouth (fig. 2). The large decrease in LRS catches at these sites between 2008 and 2009 suggests that LRS were transported north through Tulana in 2008 but not in 2009, consistent with model simulation results, and indicates that LRS may be better described by the assumptions of passive transport than SNS/KLS.

Site-specific model simulations are more difficult to verify than generalized, large-scale patterns. Density simulations of larval transport each spring during 2006-09 predicted that the proportion of larvae flowing into Upper Klamath Lake at the mouth of the Williamson River would decrease markedly in response to the breaching of levees around Tulana and Goose Bay in late 2007 and 2008. Observations at one plankton net site offshore of the Williamson River mouth indicated that catches decreased between 2008 and 2009 (fig. 12; peak catches at site 25981 were 14.5 and 0.2 fish per cubic meter in 2008 and 2009, respectively). Larval catches at the larval trawl Williamson River mouth site (U6) decreased markedly in 2008 and 2009 relative to 2006, which was a year notable for high larval trawl catches among the 14-year period of 1995-2008, but not relative to 2007, which was a year of only moderate larval trawl catches over the same period (Simon and others, 2009; fig. 13). The relative increase in densities along the Goose Bay shoreline at site U5 relative to site U6 that the model predicted for 2009 was not observed. Peak larval catches were 43.8, 32.5, 9.7, and 3.0 fish per cubic meter at U5, and 81.5, 13.9, 24.2, and 35.6 fish per cubic meter at U6 from 2006 to 2009, respectively (fig. 13). Additionally, model simulation results indicated that very few larvae would be detected in Agency Lake prior to 2008, but the Agency Lake catches were greatest in 2006, just as they were in Upper Klamath Lake (fig. 14).

Density simulations showed that larvae at concentrations of between 20 and 50 fish per cubic meter at the Modoc Point Road bridge would have concentrations less than 1 fish per cubic meter when dispersed passively to sites located more than a few kilometers away from the Williamson River channel. Given the low simulated densities in areas of the Delta far from the Williamson River channel and in Upper Klamath and Agency Lakes, larval catches might be expected to be dominated by zero catches, and correlations with simulated densities might be expected to have little or no significance. This is because larval fish are not expected to be uniformly distributed within a 100-200 m area around a sample site, but are expected to be clustered instead. Further, because each net sampled only a fraction of the simulated volume used to predict density at a site, we should have expected numerous zero catches. Rank correlation coefficients, however, were almost uniformly positive and often significant. Most significant rank correlations were about $0.30-0.60$, suggesting that although the model predicts the general pattern of distribution, usually less than one-half of the variation in site densities was explained. 
Correlations between simulated densities and larval catches based on size class showed that correlation coefficients were highest and most often significant for small larvae $(10-13 \mathrm{~mm})$ at plankton net and pop net sites, and for medium larvae $(>13 \mathrm{~mm}-16 \mathrm{~mm})$ at plankton net and larval trawl sites. The correlations for large larvae $(>16 \mathrm{~mm}-19 \mathrm{~mm})$ were highest and most consistently positive at larval trawl sites, although correlations for large larvae were significant only in 2009. Although not significant, most negative correlations were for large larvae at pop net sites. Small larvae made up 87 percent of all larvae at plankton net sites, 36.2 percent at pop net sites, and 34.1 percent at larval trawl sites. Further, at the larval trawl site closest to the larval source at the mouth of the Williamson River (U6), the small size class made up 59.4 percent of the catch and was similar to the plankton net samples.

These patterns reflect site locations because most sites closest to the river source where the smallest larvae dominated were pop net sites, and most sites farthest from the source where larger larvae were most likely to be found were larval trawl sites (fig. 2). The patterns also partly reflect the size of gear openings, because the smallest openings are in plankton nets. The gear type (or the physical setting associated with the gear type, such as vegetation presence or water depth) may have influenced the total catch density as well as the proportion of each size class caught. For example, the plankton net site 25535 was located close to the pop net site $\mathrm{B}$, and simulated densities at these two sites were comparable, but the catch densities differed markedly in both 2008 and 2009 (fig. 12). Another comparison between sites 25979 and A1 (fig. 14) shows lower catches in plankton nets than in larval trawls in Agency Lake where the model simulated similar densities. Therefore, although all nets were assumed to be maximally efficient for the smallest larvae, a better understanding of size efficiency of nets is needed to rigorously partition spatial patterns from gear-specific patterns. Additionally, each net sampled different parts of the water column, so in addition to spatial and gear differences, ontogenetic shifts in larval sucker behavior also could account for some of the variation. The youngest larvae feed in the water column, and over time a gradual transition to benthic feeding occurs. Although the approximate 50 percent surface-to-50 percent benthic diet transition occurs at a length of about $20 \mathrm{~mm}$, individuals vary greatly and benthic foods can make up 25 percent or more of the diet in a $15 \mathrm{~mm}$ larva (Markle and Clauson, 2006), which indicates that gradual and variable vertical transition in orientation is a likely cause for some of the differences observed in catches.

Variation in the duration of nighttime-only drift in 2009 had no noticeable effect on correlations. However, density simulations showed that nighttime-only drift throughout the channel would be manifested at sites close to the channel as nearly zero daytime densities, as larvae left the channel in "pulses" at night only. Yet, the highest larval catch densities were at sites A and B, which were close to the channel, and where catches were made during the day. This could imply that the nighttime-only drift behavior of the larvae does not persist far below the upstream boundary at Modoc Point Road bridge, either because of an ontogenetic shift, or because the transition from well-defined channel to open-channel sides at the Delta boundary makes it difficult or impossible for the fish to sustain the behavior. Prior to Delta restoration, larvae left the drift during the day by moving to areas with lower currents at the channel sides (Cooperman and Markle 2003). After restoration, this may simply have become more difficult where the channel is no longer constrained and water moves freely over the banks. Some other form of behavior also could be implied, however, such as the ability of even the youngest larvae to hold their position in vegetation or other suitable habitat, in which case the assumption of passive transport made in the model would break down for individuals reaching such habitats.

The field data provided moderate levels of corroboration for density based simulations. However, there are many sources for disconnects in biophysical models such as this (Leis, 2007), and our approach highlights some weaknesses that need to be improved for both the field data and the simulations.

Although our size-based spatial patterns tended to corroborate simulations, as noted previously, potential differences in gear efficiencies for different sized larvae need to be determined to more rigorously define those patterns. Intra- and inter-gear differences in efficiencies are seldom mentioned in larval dispersal modeling (Leis, 2007), with most researchers simply acknowledging that different gears deployed in different ways in the same place sometimes give different results (Overton and Rulifson, 2007). Estimates of size selection curves (Millar and Fryer, 1999) would be a first step to improving field data.

The models also predicted very low densities outside the river. If fish are uniformly distributed, these densities are close to a "density detection limit" for the gear types used, and there is likely to be a great deal of imprecision in the larval catches. For example, at one larva per net, the larval trawl detection limit was between 0.14 and 2 fish per cubic meter; the pop net detection limit between 0.37 and 3.0 fish per cubic meter; and the plankton net detection limit between 0.012 and 3.7 fish per cubic meter. Our field data and models also differed in temporal scale. The coarse temporal resolution (once every week to once every 3 weeks) of the larval catches contrasted with the time scale of the models. For example, it was not possible to determine true peak densities at fixed sites, and 
to compare them directly to the peak densities at the Modoc Point Road bridge when simulations predicted a decrease in the proportion of larvae exiting the Williamson River mouth after levees were breached. Both of these problems typically require more samples or sampling in a different manner, such as adaptive sampling (Thompson, 2002).

Overall, the model simulations showed that a primary objective of Delta restoration- to provide nursery habitat for larval suckers—-was met (David Evans and Associates, 2005). Prior to restoration, the larval plume entered Upper Klamath Lake at a single point on the shoreline corresponding to the mouth of the Williamson River (Erdman and others, 2011). After restoration, the larval plume was simulated to leave the Williamson River channel and spread out on both sides of the Delta, before entering Upper Klamath Lake through several different openings in old levees, including openings into Agency Lake. Once both sides of the Delta were restored, the model simulation results showed that the plume was likely to spread more quickly and at a higher concentration through the Goose Bay side of the Delta under prevailing wind conditions. Because basic validation for the model has been provided by the comparison to larval catch data, it can now be used with some confidence to simulate the transport of the larval plume under varying conditions of flow, lake elevation, and wind (Wood, 2012). The model also can be used to predict how larval transport will change in the future as Delta vegetation matures, if the drag of various vegetation types is accurately incorporated and an accurate map of vegetation in the Delta is made available. Finally, a potentially important use of the model is to guide larval sucker sampling programs.

Simulations would be improved by a better understanding of larval non-passive behavior. The first important step would be to determine when the ontogenetic shift to non-passive transport occurs in order to understand how long the simulated plume can be expected to represent realistically the dispersal of a cohort. At least two other aspects of non-passive behavior can be identified. First, the model would be improved by a better understanding of how far down the Williamson River channel the nighttime-only drift behavior persists. Second, strong swimming behavior, if completely random, would have the effect of increasing the effective dispersion of the larval plume. Such behavior could be simulated using the advection/diffusion approach that was used for this study by using a larger diffusivity coefficient in the model. Other types of non-passive behavior would potentially require a different approach. For example, the modeling approach used here cannot simulate the behavior if certain types of vegetation or a particular depth range act as "attractors" to the larvae, causing them to avoid passive transport, slow down, and accumulate in certain areas. A different approach, such as particle tracking, could be used to simulate such behavior.

\section{Summary}

Endangered suckers endemic to Upper Klamath Lake spawn in the Williamson River and its tributary, the Sprague River, and the larvae drift downstream to Upper Klamath Lake. A major recovery effort for endangered suckers in Upper Klamath Lake has been predicated on the assumption that recovery of deltaic marshes at the mouth of the Williamson River would help retain larvae in the lake and provide important nursery habitat. We used the UnTRIM twodimensional finite difference hydrodynamic model running on an unstructured grid to investigate the effects of deltaic modifications that occurred between 2007 and 2009 on the distribution of larval suckers. We compared model simulation results to larval catches for years before and after old levees were breached in the Williamson River Delta to validate the model assumptions. We constructed advection-diffusion based density simulations to describe the effects of deltaic modifications on larval transport, under the assumption that the larvae drift passively in the currents. These simulations were compared to larval catches at the mouth of the Williamson River and along the shorelines in Upper Klamath and Agency Lakes and the Williamson River Delta.

Model simulation results showed that the density of passively transported larvae through the Williamson River Delta would be expected to decrease along shorelines in Upper Klamath Lake after the flooding of restored wetlands. Larvae that previously entered the lake at one location-the mouth of the Williamson River-will now enter Agency and Upper Klamath Lakes at multiple locations through breaches in the levees and over submerged levees that surround the Williamson River Delta. The model simulation results indicated that prevailing winds would cause larval aggregations to be advected to a larger extent through Goose Bay than through Tulana.

Results from density simulations were compared to field data using rank correlation. Correlation coefficients were almost uniformly positive and often significant, but most were about $0.30-0.60$, suggesting that although the model predicts the general pattern of distribution, usually less than one-half of the variation in site rank densities was explained. When the density simulations were correlated with fish catches grouped into different size classes, the correlation coefficients were higher for small larvae near the larval source in the river and for larger larvae farthest from the source. The correlations were generally higher in years and with gear types in which shortnose/Klamath largescale larvae dominated, indicating that the assumptions used in the model better described the transport of shortnose/Klamath largescale than Lost River suckers. 
We also used modeling to understand the implications of nighttime-only drift behavior on larval sucker dispersal. We incorporated nighttime-only drift by "freezing" the density in the river channel during the day. Variation in the duration of nighttime drift (defined as the distance down the river channel the behavior persists) had no noticeable effect on correlations between the simulated densities and the larval catches.

Our field data provided moderate levels of corroboration for the model and showed that current patterns through the modified landscape at the Williamson River Delta are an important component of larval sucker dispersal. Better field data for model validation will be difficult to obtain, but at a minimum require information on gear size efficiency, more sampling, and different sampling strategies.

\section{Acknowledgments}

Matthew Abel, Ernest Chen, Nathan Harris, Anna Willard, Terra Kemper, James Latshaw, Randal Lodges, and Daniel T. Brown of the U.S. Geological Survey assisted field collection for USGS. Assistance with The Nature Conservancy's larval fish sampling was provided by Carolyn Doehring, Ross Egenolf, Pam Kostka, Christopher Patterson, Ariel Patushnik, Melody Warner, and Carla Wise. The Nature Conservancy specimen collections were authorized under a series of Oregon scientific taking permits through OR200914107, U.S. Fish and Wildlife Service scientific taking permits TE041204-0 and TE041201-2. Dave Simon and Mark Terwilliger led field collections and data management for the Oregon State University collections with student assistants: Sara Akins, G. Antonio Cordero, Jenna Gelardi, Jake Godfrey, Kirsten Heesacker, Cara Holem, Justin Huff, Mark Jansen, Thomas Litwin, Elizabeth Quimba, Tamal Reece, Autumn Smith, Kate Spangler, Kevin Stertz, and Dax Strubb. Oregon State University specimen collections were authorized under a series of Oregon scientific taking permits through OR200914285, U.S. Fish and Wildlife Service scientific taking permit TE006333-13, and OSU Institutional Animal Care and Use permit LAR-ID 3619.

This report was funded by the Bureau of Reclamation as part of Bureau of Reclamation's mission to manage, develop, and protect water and related resources in an environmentally and economically sound manner in the interest of the American public. Funding was provided through Interagency Agreement 08AA200098 and contracts 1434-03HQRU1584 and \#2-FG-81-0813. The views in this report are the authors' and do not necessarily represent the views of Reclamation. Additional funding was provided by the U.S. Geological Survey and the Oregon Agricultural Experiment Station.

\section{References Cited}

Arnold, W.S., Hitchcock, G.L., Frischer, M.E., Wanninkhof, R., and Sheng, Y.P., 2005, Dispersal of an introduced larval cohort in a coastal lagoon: Limnology and Oceanography, v. 50, no. 2, p. 587-597.

Beletsky, Dmitry, Mason, D.M., Schwab, D.J., Rutherford, E.S., Janssen, John, Clapp, D.F., and Dettmers, J.M., 2007, Biophysical model of larval yellow perch advection and settlement in Lake Michigan: Journal of Great Lakes Research, v. 33, p. 842-866.

Buccola, N.L., and Wood, T.M., 2010, Empirical models of wind conditions on Upper Klamath Lake, Oregon: U.S. Geological Survey Scientific Investigations Report 2010-5201, 26 p. (Also available at http://pubs.usgs.gov/ $\underline{\text { sir/2010/5201/.) }}$

Burdick, S.M., and Brown, D.T., 2010, Distribution and condition of larval and juvenile Lost River and shortnose suckers in the Williamson River Delta restoration project and Upper Klamath Lake, Oregon-2009 annual data summary: U.S. Geological Survey Open-File Report 2010-1216, 78 p. (Also available at http://pubs.usgs.gov/ of/2010/1216/.)

Burdick, S.M., Ottinger, Christopher, Brown, D.T., VanderKooi, S.P., Robertson, Laura, and Iwanowicz, Deborah, 2009, Distribution, health, and development of larval and juvenile Lost River and shortnose suckers in the Williamson River Delta restoration project and Upper Klamath Lake, Oregon-2008 annual data summary: U.S. Geological Survey Open-File Report 2009-1287, 76 p. (Also available at http://pubs.usgs.gov/of/2009/1287/.)

Burdick, S.M., and Vanderkooi, S.P., 2010, Temporal and spatial distribution of endangered juvenile Lost River and shortnose suckers in relation to environmental variables in Upper Klamath Lake, Oregon-2008 annual data summary: U.S. Geological Survey Open-File Report 2010-1051, 36 p. (Also available at http://pubs.usgs.gov/of/2010/1051/.)

Casulli, Vincenzo, and Zanolli, P., 2002, Semi-implicit numerical modeling of nonhydrostatic free-surface flows for environmental problems: Mathematical and Computer Modelling, v. 36, p. 1131-1149.

Cooperman, M.S., and Markle, D.F., 2003, Rapid out-migration of Lost River and shortnose sucker larvae from in-river spawning beds to in-lake rearing grounds: Transactions of the American Fisheries Society, v. 132, p. 1138-1153. 
Cooperman, M.S., and Markle, D.F., 2004, Abundance, size and feeding success of larval shortnose and Lost River suckers from different habitats of the littoral zone of Upper Klamath Lake: Environmental Biology of Fishes, v. 71, p. 365-377.

Cooperman, M.S., Markle, D.F., Terwilliger, Mark, and Simon, D.C., 2010, A production estimate approach to analyze habitat and weather effects on recruitment of two endangered freshwater fish: Canadian Journal of Fisheries and Aquatic Sciences, v. 67, p. 28-41.

Crandall, J.D., Bach, L.B., Rudd, Nathan, Stern, Mark, and Barry, Matt, 2008, Response of larval Lost River and shortnose suckers to wetland restoration at the Williamson River Delta, Oregon: Transactions of the American Fisheries Society, v. 137, p. 402-416.

Cunningham, M.K., Granberry, W.F., Jr., and Pope, K.L., 2000, Shrinkage of inland silverside larvae preserved in ethanol and formalin: North American Journal of Fisheries Management, v. 20, p. 816-818.

Daraio, J.A., Randle, T.J., and Bach, L.B., 2004, Lower Williamson River floodplain and delta restorationHydraulic modeling: Denver, Colo., Bureau of Reclamation Technical Service Center, 89 p.

David Evans and Associates, 2005, Final Williamson River Delta environmental impact statement: Portland, Oreg., prepared for Natural Resources Conservation Service, The Nature Conservancy, Portland, Oreg., and the Bureau of Reclamation, Klamath Falls, Oreg., 185 p. plus appendices.

Ellien, Celine, Thiébaut, Eric, Dumas, Franck, Salomon, J.C., and Nival, Paul, 2004, A modelling study of the respective role of hydrodynamic processes and larval mortality on larval dispersal and recruitment of benthic invertebratesExample of Pectinaria koreni (Annelida: Polychaeta) in the Bay of Seine (English Channel): Journal of Plankton Research, v. 26, no. 2, p. 117-132.

Ellsworth, C.M., Banks, D.T., and VanderKooi, S.P., 2011, Patterns of larval sucker emigration from the Sprague and lower Williamson Rivers of the Upper Klamath Basin, Oregon, prior to the removal of Chiloquin Dam2007/2008 annual report: U.S. Geological Survey Open-File Report 2011-1108, 30 p. (Also available at http://pubs.usgs. gov/of/2011/1108/.)

Ellsworth, C.M., Tyler, T.J., and VanderKooi, S.P., 2010, Using spatial, seasonal, and diel drift patterns of larval Lost River suckers Deltistes luxatus (Cypriniformes: Catostomidae) and shortnose suckers Chasmistes brevirostris (Cypriniformes: Catostomidae) to help identify a site for a water withdrawal structure on the Williamson River, Oregon: Environmental Biology of Fishes, v. 89, no. 1, p. 47-57. DOI 10.1007/s10641-010-9688-8.
Ellsworth, C.M., Tyler, T.J., VanderKooi, S.P., and Markle, D.F., 2009, Patterns of larval sucker emigration from the Sprague and lower Williamson Rivers of the Upper Klamath Basin, Oregon, prior to the removal of Chiloquin Dam2006 annual report: U.S. Geological Survey Open-File Report 2009-1027, 32 p. (Also available at http://pubs.usgs. gov/of/2009/1027/.)

Erdman, C.S., and Hendrixson, H.A., 2009, Larval shortnose and Lost River sucker response to large scale wetland restoration of the north half of the Williamson River Delta preserve, Oregon: Klamath Falls, Oreg., The Nature Conservancy, Oregon, 27 p.

Erdman, C.S., and Hendrixson, H.A., 2010, Larval Lost River and shortnose sucker response to large scale wetland restoration at the Williamson River Delta preserve-2009 annual data summary: Klamath Falls, Oreg., The Nature Conservancy, $38 \mathrm{p}$.

Erdman, C.S, Hendrixson, H.A., and Rudd, N.T., 2011, Larval sucker distribution and condition before and after largescale restoration at the Williamson River Delta, Upper Klamath Lake, Oregon: Western North American Naturalist. v. 71, p. 472-480.

Gerlach, Gabriele, Atema, Jelle, Kingsford, M.J., Black, K.P., and Miller-Sims, Vanessa, 2007, Smelling home can prevent dispersal of reef fish larvae: Proceedings of the National Academy of Sciences, v. 104, p. 858-863.

Graham Matthews and Associates, 2001, Geomorphic and hydraulic analysis of the Williamson River restoration project-Year 2000 riverbend site: Portland, Oreg., prepared for The Nature Conservancy of Oregon, 31 p.

Graham Matthews and Associates, 2009, Fourmile-Sevenmile restoration assessment project: Weaverville, Calif., prepared for U.S. Fish and Wildlife Service, Klamath Falls, Oreg., $138 \mathrm{p}$.

Hare, J.A., Churchill, J.H., Cowen, R.K., Berger, T., Cornillon, P., Dragos, P., Glenn, S., Govoni, J.J., and Lee, T.N., 2002, Routes and rates of larval fish transport from the southeast to the northeast United States continental shelf: Limnology and Oceanography, v. 47, p. 1774-1789.

Hendrixson, H.A., 2008, Non-native fish species and Lost River and shortnose suckers use of restoration and undisturbed wetlands at the Williamson River Delta-Final report to Bureau of Reclamation for activities conducted in 2006 and 2007: Klamath Falls, Oreg., U.S. Geological Survey Western Fisheries Research Center, 28 p. 
Hinckley, S., Megrey, B.A., and Miller, Thomas, 2009, Application 3-Recruitment prediction, in North, E.W., Gallego, Alejandro, and Petitgas, Pierre, eds., Manual of recommended practices for modelling physical-biological interactions during fish early life: ICES Cooperative Research Report No. 295, p. 77-82.

Houde, E.D., and Bartsch, J., 2009, Mortality, in North, E.W., Gallego, Alejandro, and Petitgas, Pierre, eds., Manual of recommended practices for modelling physical-biological interactions during fish early life: ICES Cooperative Research Report No. 295, p. 27-42.

Houde, E.D., and Zastrow, C.E., 1993, Ecosystem- and taxon-specific dynamic energetics properties of fish larvae assemblages: Bulletin of Marine Science, v. 53, no. 2, p. 290-335.

Janney, E.C., Shively, R.S., Hayes, B.S., Barry, P.M., and Perkins, D., 2008, Demographic analysis of Lost River sucker and shortnose sucker populations in Upper Klamath Lake, Oregon: Transactions of the American Fisheries Society, v. 137, p. 1812-1825.

LaBolle, L.D., Jr., Li, H.W., and Mundy, B.C., 1985, Comparison of two samplers for quantitatively collecting larval fishes in upper littoral habitats: Journal of Fish Biology, v. 26, p. 139-146.

Leis, J.M., 2007, Behaviour as input for modelling dispersal of fish larvae-Behaviour, biogeography, hydrodynamics, ontogeny, physiology and phylogeny meet hydrography: Marine Ecology Progress Series, v. 347, p. 185-193.

Mariani, Patrizio, MacKenzie, B.R., Iudicone, D., and Bozec, A., 2010, Modelling retention and dispersion mechanisms of bluefin tuna eggs and larvae in the northwest Mediterranean Sea: Progress in Oceanography, v. 86, p. $45-58$.

Markle, D.F., Cavalluzzi, M.R., and Simon, D.C., 2005, Morphology and taxonomy of Klamath Basin suckers (Catostomidae): Western North American Naturalist, v. 65, p. 473-489.

Markle, D.F., and Clauson, K., 2006, Ontogenetic and habitat-related changes in diet of late larval and juvenile suckers (Catostomidae) in Upper Klamath Lake, Oregon: Western North American Naturalist, v. 66, p. 492-501.

Markle, D.F., and Dunsmoor, L.K., 2007, Effects of habitat volume and fathead minnow introduction on larval survival of two endangered sucker species in Upper Klamath Lake, Oregon: Transactions of the American Fisheries Society, v. 136, p. 567-579.
Markle, D.F., Reithel, S.A., Crandall, J., Wood, T., Tyler, T.J., Terwilliger, M., and Simon, D.C., 2009, Larval fish transport and retention and the importance of location for juvenile fish recruitment in Upper Klamath Lake, Oregon: Transactions of the American Fisheries Society, v.138, p. 328-347.

Millar, R.B., and Fryer, R.J., 1999, Estimating the size-selection curves of towed gears, traps, nets and hooks: Reviews in Fish Biology and Fisheries, v. 9, no. 1, p. 89-116.

Nahas, E.L., Jackson, G., Pattiaratchi, C.B., and Ivey, G.N., 2003, Hydrodynamic modeling of snapper Pagrus auratus egg and larval dispersal in Shark Bay, Western AustraliaReproductive isolation at a fine spatial scale: Marine Ecology Progress Series, v. 265, p. 213-226.

Overton, A.S., and Rulifson, R.A., 2007, Evaluation of plankton surface pushnets and oblique tows for comparing the catch of diadromous larval fish: Fisheries Research, v. 86, p. 99-104.

Paris, C.B., Irisson, J.O., Lacroix, G., Fiksen, O., Leis, J.M., and Mullon, C., 2009, Application 2-Connectivity, in North, E.W., Gallego, Alejandro, and Petitgas, Pierre, eds., Manual of recommended practices for modelling physicalBiological interactions during fish early life: ICES Cooperative Research Report No. 295, p. 63-76.

Pepin, Pierre, Werner, Cisco, and van der Molen, Johan, 2009, Application 1-Adaptive sampling, in North, E.W., Gallego, Alejandro, and Petitgas, Pierre, eds., Manual of recommended practices for modelling physical-biological interactions during fish early life: ICES Cooperative Research Report No. 295. p. 60-62.

Petrone, C., Jancaitis, L.B., Jones, M.B., Natunewicz, C.C., Tilburg, C.E., and Epifanio, C.E., 2005, Dynamics of larval patches-Spatial distribution of fiddler crab larvae in Delaware Bay and adjacent waters, Marine Ecology Progress Series, v. 293, p. 177-190.

Potthoff, T., 1984, Clearing and staining techniques, in Moser, H.G., editor-in-chief, Ontogeny and systematics of fishes: Lawrence, Kans., American Society of Ichthyologists and Herpetologists, Special Publication No. 1, p. 35-37.

Reiser, D.W., Loftus, M., Chapin, D., Jeanes, E., and Oliver, K., 2001, Effects of water quality and lake level on the biology and habitat of selected fish species in Upper Klamath Lake: Portland, Oreg., report to the Bureau of Indian Affairs, R2 Resource Consultants, Inc., Redmond, Wash., variously paged.

Reyns, N.B., Eggleston, D.B., and Luettich, R.A., Jr., 2006, Secondary dispersal of early juvenile blue crabs within a wind-driven estuary: Limnology and Oceanography, v. 51, no. 5, p. 1982-1995. 
Scoppettone, G.G., and Vinyard, G., 1991, Life history and management of four endangered lacustrine suckers, in Minckley, W.L., and Deacon, J.E., eds., Battle against extinction-Active fish management in the American West: Tucson, Ariz., University of Arizona Press, p. 359-377.

Simon, D.C., Terwilliger, M.R., and Markle, D.F., 2009, Larval and juvenile ecology of Upper Klamath Lake suckers-2004-2008, Final report for contract 143403HWRU1584 submitted to U.S. Bureau of Reclamation, Klamath Falls, Oreg.: Corvallis, Oregon State University, Department of Fisheries and Wildlife, 174 p.

Terwilliger, M.R., Markle, D.F., and Kann, Jacob, 2003, Associations between water quality and daily growth of juvenile shortnose and Lost River suckers in Upper Klamath Lake, Oregon: Transactions of the American Fisheries Society, v. 132, p. 691-708.

Terwilliger, M.R., Reece, T., and Markle, D.F., 2010, Historic and recent age structure and growth of endangered Lost River and shortnose suckers in Upper Klamath Lake, Oregon: Environmental Biology of Fishes, v. 89, p. 239252.

Thompson, S.K., 2002, Sampling, 2nd ed.: New York, Wiley.

Tyler, T.J., Ellsworth, C.M., Shively, R.S., and VanderKooi, S.P., 2004, Larval sucker drift in the Lower Williamson River, Oregon-Evaluation of two proposed water diversion sites for the Modoc Point Irrigation District: Klamath Falls, Oreg., U.S. Geological Survey Western Fisheries Research Center Data Summary.
Ware, D.M., 1975, Relation between egg size, growth, and natural mortality of larval fish: Journal of the Fisheries Research Board of Canada, v. 32, p. 2503-2512.

Watson, J.R., Mitarai, S., Siegel, D.A., Caselle, J.E., Dong, C., and McWilliams, J.C., 2010, Realized and potential larval connectivity in the Southern California bight: Marine Ecology Progress Series, v. 401, p. 31-48.

Wood, T.M., 2012, Dependence of flow and transport through the Williamson River Delta, Upper Klamath Lake, Oregon, on wind, river inflow, and lake elevation: U.S. Geological Survey Scientific Investigations Report 2012-5004, 32 p. (Also available at http://pubs.usgs.gov/sir/2012/5004/.)

Wood, T.M., Cheng, R.T., Gartner, J.W., Hoilman, G.R., Lindenberg, M.K., and Wellman, R.E., 2008, Modeling hydrodynamics and heat transport in Upper Klamath Lake, Oregon, and implications for water quality: U.S. Geological Survey Scientific Investigations Report 2008-5076, 48 p. (Also available at http://pubs.usgs.gov/sir/2008/5076/.)

Wright, K.J., Higgs, D.M., and Leis, J.M., 2011, Ontogenetic and interspecific variation in hearing ability in marine fish larvae: Marine Ecology Progress Series, v. 424, p. 1-13. 
Publishing support provided by the U.S. Geological Survey

Publishing Network, Tacoma Publishing Service Center

For more information concerning the research in this report, contact the Director, Oregon Water Science Center

U.S. Geological Survey

2130 SW 5th Avenue

Portland, Oregon 97201

http://or.water.usgs.gov 
